\title{
Ecological Energetic Perspectives on Responses of Nitrogen-Transforming Chemolithoautotrophic Microbiota to Changes in the Marine Environment
}

\author{
Hongyue Dang ${ }^{1 *}$ and Chen-Tung A. Chen ${ }^{2}$ \\ ${ }^{1}$ State Key Laboratory of Marine Environmental Science, Institute of Marine Microbes and Ecospheres, College of Ocean \\ and Earth Sciences, Xiamen University, Xiamen, China, ${ }^{2}$ Department of Oceanography, National Sun Yat-sen University, \\ Kaohsiung, Taiwan
}

OPEN ACCESS

Edited by:

Karla B. Heidelberg, University of Southern California,

United States

Reviewed by:

Zhe-Xue Quan,

Fudan University, China

Martin Koenneke,

MARUM - Center for Marine

Environmental Sciences, University

of Bremen, Germany

*Correspondence:

Hongyue Dang

danghy@xmu.edu.cn

Specialty section:

This article was submitted to

Aquatic Microbiology,

a section of the journal

Frontiers in Microbiology

Received: 07 December 2016 Accepted: 20 June 2017

Published: 14 July 2017

Citation:

Dang $\mathrm{H}$ and Chen C-TA (2017) Ecological Energetic Perspectives on Responses of Nitrogen-Transforming

Chemolithoautotrophic Microbiota to Changes in the Marine Environment.

Front. Microbiol. 8:1246.

doi: 10.3389/fmicb.2017.01246
Transformation and mobilization of bioessential elements in the biosphere, lithosphere, atmosphere, and hydrosphere constitute the Earth's biogeochemical cycles, which are driven mainly by microorganisms through their energy and material metabolic processes. Without microbial energy harvesting from sources of light and inorganic chemical bonds for autotrophic fixation of inorganic carbon, there would not be sustainable ecosystems in the vast ocean. Although ecological energetics (eco-energetics) has been emphasized as a core aspect of ecosystem analyses and microorganisms largely control the flow of matter and energy in marine ecosystems, marine microbial communities are rarely studied from the eco-energetic perspective. The diverse bioenergetic pathways and eco-energetic strategies of the microorganisms are essentially the outcome of biosphere-geosphere interactions over evolutionary times. The biogeochemical cycles are intimately interconnected with energy fluxes across the biosphere and the capacity of the ocean to fix inorganic carbon is generally constrained by the availability of nutrients and energy. The understanding of how microbial eco-energetic processes influence the structure and function of marine ecosystems and how they interact with the changing environment is thus fundamental to a mechanistic and predictive understanding of the marine carbon and nitrogen cycles and the trends in global change. By using major groups of chemolithoautotrophic microorganisms that participate in the marine nitrogen cycle as examples, this article examines their eco-energetic strategies, contributions to carbon cycling, and putative responses to and impacts on the various global change processes associated with global warming, ocean acidification, eutrophication, deoxygenation, and pollution. We conclude that knowledge gaps remain despite decades of tremendous research efforts. The advent of new techniques may bring the dawn to scientific breakthroughs that necessitate the multidisciplinary combination of eco-energetic, biogeochemical and "omics" studies in this field.

Keywords: carbon cycle, chemolithoautotrophy, energy metabolism, global change, global warming, nitrogen cycle, ocean acidification, ocean deoxygenation

Abbreviations: ANME, anaerobic methane oxidation; $\mathrm{CBB}$, Calvin-Benson-Bassham cycle; rTCA, reductive tricarboxylic acid cycle; Comammox, complete oxidation of ammonia to nitrate; Anammox, anaerobic ammonium oxidation; DC/4-HB, dicarboxylate/4-hydroxybutyrate cycle; WL, Wood-Ljungdahl pathway (i.e., reductive acetyl-CoA pathway); 3-HP/4-HB, 3hydroxypropionate/4-hydroxybutyrate cycle. 


\section{INTRODUCTION}

Ecological energetics (eco-energetics) is the study of energy flow and transformations in an ecosystem or through a population in a specific environment (Odum, 1968). Energy flow is a basic property of any ecosystem. From sunlit seawater to dark deep ocean and marine sediments, microorganisms employ various energy-transducing strategies to carry out ecological and biogeochemical functions (Kolber, 2007; Falkowski et al., 2008). The diverse microbial eco-energetic strategies are essentially a result of evolution during long-term biosphere-geosphere interactions (Nitschke et al., 2013; Sousa et al., 2013; Jelen et al., 2016), as vitally put by Lane et al. (2013): "if nothing in biology makes sense except in the light of evolution, nothing in evolution makes sense except in the light of energetics."

Microorganisms constitute the most abundant, diverse and metabolically active component of biomass in the marine environment (Azam, 1998; Kallmeyer et al., 2012). The microbial communities largely control the flow of energy from abiotic forms to higher trophic levels in the ocean (Azam et al., 1983; DeLong, 2009; Brown et al., 2014). For example, marine photolithoautotrophic and chemolithoautotrophic microorganisms harvest and transform energy from otherwise largely bio-inaccessible sources (e.g., light and inorganic chemical bonds) to forms useable by chemoorganoheterotrophic consumers such as protists and animals (Brown et al., 2014). With this primary eco-energetic service, microorganisms set and control the reduction-oxidation (redox) and energy states of their environment, provide ecological services and influence the climate-mediating potential of the ocean (Azam and Malfatti, 2007; Falkowski et al., 2008; Carpenter et al., 2012). Energy is the ultimate limiting factor in determining the structure and function of the Earth ecosystem (Odum, 1968). While this makes eco-energetics "the core of ecosystem analysis" (Odum, 1968), marine microbial communities are seldomly studied from the eco-energetic perspective (Kolber, 2007; Vallino and Algar, 2016).

The marine biogeochemical cycles are driven by the microbial engines (Falkowski et al., 2008), which are mainly fuelled by energy conserved through microbial metabolic processes (Figure 1) (Falkowski and Godfrey, 2008; Orcutt et al., 2011). However, modeling studies of ecosystem metabolism including most recent ones usually ignored marine bacteria and archaea completely or considered them solely as decomposers (Heymans et al., 2014). This contradicts the diverse ecofunctions including the widespread autotrophy of the bacterial and archaeal communities in the ocean (Berg et al., 2010; Fuchs, 2011; Hügler and Sievert, 2011). In stark contrast to higher organisms such as plants and animals, bacteria and archaea employ diverse and complex energy metabolic pathways (Kolber, 2007), which are adapted to and effective in diverse environments. Microbial communities select energetically favorable electron donors and acceptors from their environment for energy transduction (Bar-Even et al., 2012; Eggleston et al., 2015). Even so, energy may be a limited resource for certain marine ecosystems (Burgin et al., 2011; Moore et al., 2013; Vallino and Algar, 2016). The sources and sustainability of energy supplies largely control the diversity and actual rates of the energy metabolic pathways and thus the composition, structure, and function of the microbial communities (Kolber, 2007; Dahle et al., 2015).

Microbial chemolithotrophic metabolism was discovered in the 1880 s by Sergei Winogradsky, a pioneer in microbial ecology (Dworkin, 2012). Similar to photolithoautotrophs, chemolithoautotrophs contribute to primary production, which is, however, fueled by energy conserved from aerobic or anaerobic oxidation of inorganic electron donors (e.g., $\mathrm{NH}_{3}, \mathrm{NH}_{4}{ }^{+}$, $\mathrm{NO}_{2}{ }^{-}, \mathrm{S}^{2-}, \mathrm{S}, \mathrm{H}_{2}, \mathrm{CO}$, and $\mathrm{Fe}^{2+}$ ). Some microorganisms are chemoorganoautotrophs that oxidize organic chemicals (e.g., $\mathrm{CH}_{4}$ ) to conserve energy for carbon fixation, such as the anaerobic methane-oxidizing (ANME) archaea (Kellermann et al., 2012).

A series of exciting discoveries of new chemoautotrophic microorganisms and their bioenergetic pathways were made around the turn of the 21st century. In 1999, for example, chemolithoautotrophic anaerobic ammonium-oxidizing (anammox) bacteria were discovered and subsequently found to be widely distributed in oxygen-deficient and oxygendepleted seawater and sediments, carrying out an important biogeochemical process in biological nitrogen removal from the ocean (Strous et al., 1999; Dalsgaard et al., 2003; Kuypers et al., 2003; Oshiki et al., 2016). The turn of the last century also witnessed the discovery of the ANME archaea and their consortial association with sulfate-reducing bacteria (Hinrichs et al., 1999; Boetius et al., 2000). ANME play an important role in the removal of methane, a potent greenhouse gas, from deep-sea cold-seep sediments and many other methane-rich environments (Knittel and Boetius, 2009; Marlow et al., 2016). Certain ANME archaea also harbor the genetic and biochemical inventory for $\mathrm{N}_{2}$ fixation (Pernthaler et al., 2008; Dang et al., 2009a, 2013a; Dekas et al., 2009; Miyazaki et al., 2009), thereby contributing to coupled carbon, sulfur, and nitrogen cycling in methane-rich, sulfate-rich but nitrogen-poor environments (Fulweiler, 2009). In 2002, neutrophilic, chemolithoautotrophic iron-oxidizing bacteria $(\mathrm{FeOB})$ were found to be abundant in deep-sea hydrothermal vent environments (Emerson and Moyer, 2002) and they were later classified as a new class of the Proteobacteria: the Zetaproteobacteria (Emerson et al., 2007). Subsequent investigations indicate that zetaproteobacterial FeOB exist in coastal seawater and sediments as well, where they participate in coastal iron cycling and biocorrosion of man-made iron constructs (Dang et al., 2008a, 2011; McBeth et al., 2011; McBeth and Emerson, 2016). Recently, zetaproteobacterial FeOB were also discovered to utilize ferrous iron $\left(\mathrm{Fe}^{2+}\right)$ from deep-sea basaltic rocks and basaltic glasses as an energy source, thereby contributing to carbon fixation in ultra-oligotrophic abyssal plains (Orcutt et al., 2015; Henri et al., 2016).

Since their discovery in the 1880s, chemolithoautotrophic ammonia-oxidizing bacteria (AOB) were believed to be the sole microorganisms responsible for biological ammonia oxidation in oxic environments. This long-lasting misconception was refuted in 2005 by the discovery of chemolithoautotrophic ammoniaoxidizing archaea (AOA) (Francis et al., 2005; Könneke et al., 2005), which are affiliated with the newly defined phylum, Thaumarchaeota (Brochier-Armanet et al., 2008; Spang et al., 


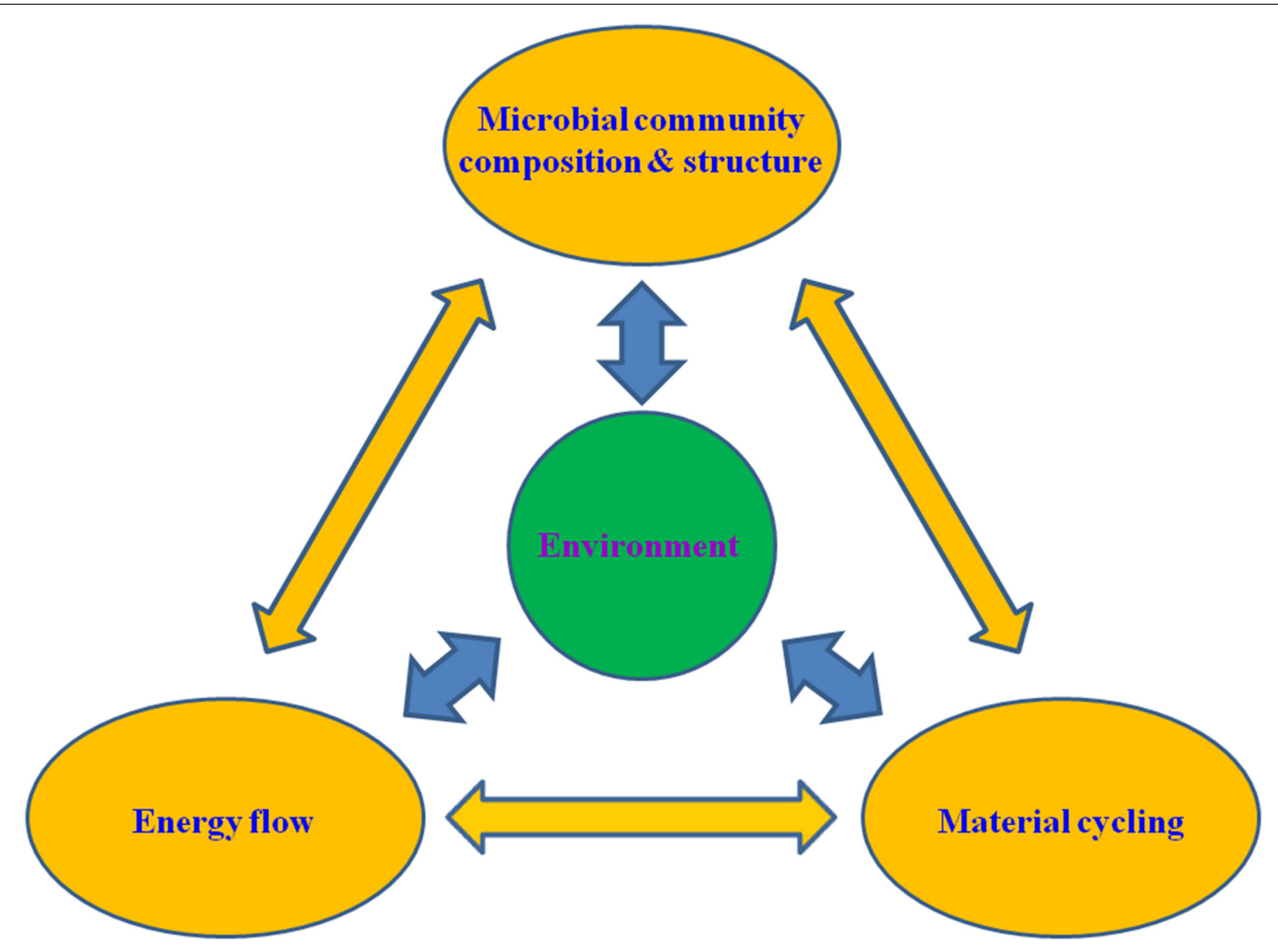

FIGURE 1 | A conceptual illustration of the interactive network involving the microbial community structure, ecophysiological functions (i.e., energy flow and material cycling) and environment. The double-headed arrows indicate potential interactions between different components and processes of the network.

2010). The most recent addition to the metabolic diversity of chemolithoautotrophic microorganisms was the bacterial strains in the nitrite-oxidizing genus Nitrospira capable of carrying out complete oxidation of ammonia to nitrate (comammox) (Daims et al., 2015; van Kessel et al., 2015). The history of chemoautotroph studies indicates that the ocean is full of surprises and opportunities of unknown microorganisms and novel bioenergetic strategies.

The discovery of chemolithoautotrophy by Winogradsky ended the long-lasting misconception that photoautotrophic organisms such as plants and algae are the sole primary producers on Earth (Dworkin, 2012). The discoveries of diverse chemolithic bioenergetic pathways contributed greatly to the understanding of the complexity of energy flow in Earth ecosystems and the interdependency of the biogeochemical cycles involving carbon, nitrogen, sulfur, iron, and other bioessential elements (Table 1). The discoveries of chemosynthetic ecosystems in the deep-sea hydrothermal vent and cold-seep environments as "oases" in the vast deep ocean "deserts" were true scientific thrills in the 70s and 80 s of the 20th century, spotlighting the cornerstone species role in community structure and the primary producer role in trophic transfer the chemoautotrophic bacteria and archaea play in these sunlight-independent marine ecosystems (Felbeck and Somero, 1982; Paull et al., 1985; Jørgensen and Boetius, 2007). They provided the first evidences about the importance of microbial chemolithoautotrophy for energy and matter flows in nature and stimulated the search of life's origin on Earth and beyond (Nisbet and Sleep, 2001; Martin et al., 2008).

Chemolithoautotrophic microorganisms may contribute substantially to primary production in non-extreme marine environments as well. For example, dark carbon fixation in the redox transition zone of the Cariaco Basin, mainly carried out by chemolithoautotrophic sulfur-oxidizing bacteria (SOB) fueled with seawater reduced sulfur species, was equivalent to $10-333 \%$ of the local surface ocean photosynthetic primary production (Taylor et al., 2001). Microbial chemolithoautotrophs also contribute substantially to primary production in oxygenated dark oceans. Carbon fixation in meso- and bathypelagic waters of the North Atlantic, presumably by chemolithoautotrophic AOA, could amount to $15-53 \%$ of phytoplankton export production from surface water (Reinthaler et al., 2010). Dark carbon fixation in Tyrrhenian deep waters of Central Mediterranean Sea by chemolithoautotrophic microorganisms (mainly affiliated with AOA) was comparable to photosynthetic production (Yakimov et al., 2011). On the global scale, seawater AOA may fix approximately $400 \mathrm{Tg} \mathrm{C} \mathrm{y}^{-1}$ (Hügler and Sievert, 2011). In the middle (i.e., the twilight zone) and deep ocean, chemolithoautotrophs also contribute to the production and accumulation of quite an amount (5-10 $\mu \mathrm{M})$ of semi-labile dissolved organic carbon (DOC) (Follett et al., 2014), which may be further transformed by microorganisms to produce recalcitrant DOC (RDOC) (Jiao et al., 2014). The average 
turnover time of deep ocean RDOC reaches millennial timescales (Hansell, 2013). Dilution and structural recalcitrance preclude microbial consumption, constituting the major mechanisms for long-term sequestration of marine RDOC (Jiao et al., 2014; Arrieta et al., 2015; Moran et al., 2016). The deep-ocean DOC concentrations maintain small $(\sim 40 \mu \mathrm{M})$ and relatively constant (Chen, 2011; Hansell, 2013), which, however, sustain active microbial communities (Arrieta et al., 2015). The in situ primary production of chemolithoautotrophs may provide an important source of organic matter, in addition to that released from sinking particles, hydrothermal vents and cold seeps (Chen, 2011), to fuel the activities of the deep-ocean microbiota. However, it is currently unknown whether the different sources of DOC (e.g., produced by in situ chemolithoautotrophs or released from sinking particles, hydrothermal vents or cold seeps) may have different molecular structures and bio-utilizabilities and thus different residence times in the ocean. Furthermore, although on average the contribution of the chemolithoautotrophic microbiota to ocean's carbon fixation may be substantial, the in situ chemolithoautotrophic carbon fixation rates are highly variable among different marine environments (Taylor et al., 2001; Reinthaler et al., 2010). The in situ energy sources (e.g., bioavailable inorganic reductants and oxidants) may exert substantial influences on the abundance, diversity, activity, distribution, and dynamics of marine chemolithoautotrophs, and thus the energy environment may play important roles in chemolithoautotrophic carbon fixation and carbon sequestration (Dang and Jiao, 2014). Further systematic investigations are needed to quantitatively understand the roles of the microbial chemolithoautotrophs in ocean's carbon budget and dynamics and in microbe-environment interactions.

Global change caused by anthropogenic activities may alter the physical, chemical and energy environment of the marine ecosystems and thus alter the spatiotemporal dynamics and functions of the microbiota (Kolber, 2007; Hutchins et al., 2009; Middelburg and Levin, 2009; Dang and Jiao, 2014). To understand how the microbial eco-energetic processes influence the structure and function of the marine ecosystems and how they respond to and exert impacts on the changing marine environment is fundamental to a mechanistic and predictive understanding of the global carbon cycle and the ocean's climate-modulating capacity. Because of the tremendous diversity of the marine microorganisms, even just considering the chemolithoautotrophs (Berg et al., 2010; Berg, 2011; Hügler and Sievert, 2011), it is practical and meaningful to divide a community into distinct functional groups in microbial eco-energetic studies. The nitrogen cycle is probably the most perturbed biogeochemical cycle due to human activities (Rockström et al., 2009). Therefore in this review, we focus on the major functional groups of chemolithoautotrophic bacteria and archaea that are involved in marine nitrogen cycling (Figure 2) to tentatively illustrate their energetic strategies, ecological processes, contributions to carbon cycling, and responses to and impacts on global change associated with global warming, ocean acidification, eutrophication, deoxygenation, and pollution.

\section{DIVERSE CHEMOLITHOAUTOTROPHIC PATHWAYS IN MARINE NITROGEN-CYCLING BACTERIA AND ARCHAEA}

Dissolved inorganic nitrogen (DIN) compounds are used as either nutrients for assimilatory biomass production or electron donors or electron acceptors that are transformed by dissimilatory cellular redox reactions for microbial energy transduction (Figure 2). Activity of chemolithoautotrophic nitrogen-cycling bacteria and archaea is generally inhibited by light (for AOB and AOA) or by oxygen (for anammox bacteria) and outcompeted by phytoplankton for ammonium uptake in the marine photic zone (Arrigo, 2005; Merbt et al., 2012; Smith et al., 2014). Thus, DIN dissimilatory utilization for energy transduction happens mainly in the twilight and dark zones of the ocean, where aerobic oxidation of ammonia and nitrite occurs under oxic and hypoxic conditions and anammox (and denitrification) occurs under suboxic and anoxic conditions.

\section{Diverse Eco-energetic Strategies of Marine Chemolithoautotrophic Nitrifying Microorganisms}

Nitrification is carried out mainly by chemolithoautotrophs, in two separated steps either by $\mathrm{AOB}$ and $\mathrm{AOA}$ for aerobic oxidation of ammonia to nitrite and NOB for aerobic oxidation of nitrite to nitrate or by comammox bacteria for the joint aerobic oxidation of ammonia and nitrite (Arp et al., 2007; Kuypers, 2015; Daims et al., 2016). Although most seawater environments in the surface ocean are oligotrophic, nitrification occurs throughout the water column, with the only exception likely in the core of the anoxic marine zones (Ulloa et al., 2012). Formation of the primary nitrite maximum (PNM) at the base of the marine euphotic zone in stratified water columns may be caused by phytoplankton excretion (Lomas and Lipschultz, 2006; Beman et al., 2012). However, recent studies have shown that ammonia oxidation by AOA may actually produce the major source of nitrite in PNM (Beman et al., 2013; Buchwald and Casciotti, 2013; Santoro et al., 2013). Ammonia oxidation by AOA also contributes, to variable degrees, to the formation of the secondary nitrite maximum frequently observed in the oceanic oxygen minimum zones (OMZs) (Lam et al., 2011). AOA constitute the most abundant functional group of microorganisms in the ocean's mesopelagic and bathypelagic zones (Kirchman et al., 2007; Bristow et al., 2015), and they play a major role in nitrification and dark carbon fixation in the interior of the ocean (Herndl et al., 2005; Ingalls et al., 2006; Follett et al., 2014; Berg et al., 2015a). The deep oceans maintain a large reservoir of nitrate, associated mainly with the in situ AOA abundance (Herndl et al., 2005; Yakimov et al., 2011).

Ammonia-oxidizing archaea are usually more abundant and active than $\mathrm{AOB}$ in the ocean, particularly in oligotrophic environments (Stahl and de la Torre, 2012; Corinaldesi, 2015). The prevalence of nitrifying activity by marine AOA is mainly due to their extremely high specific affinity for ammonia and their 


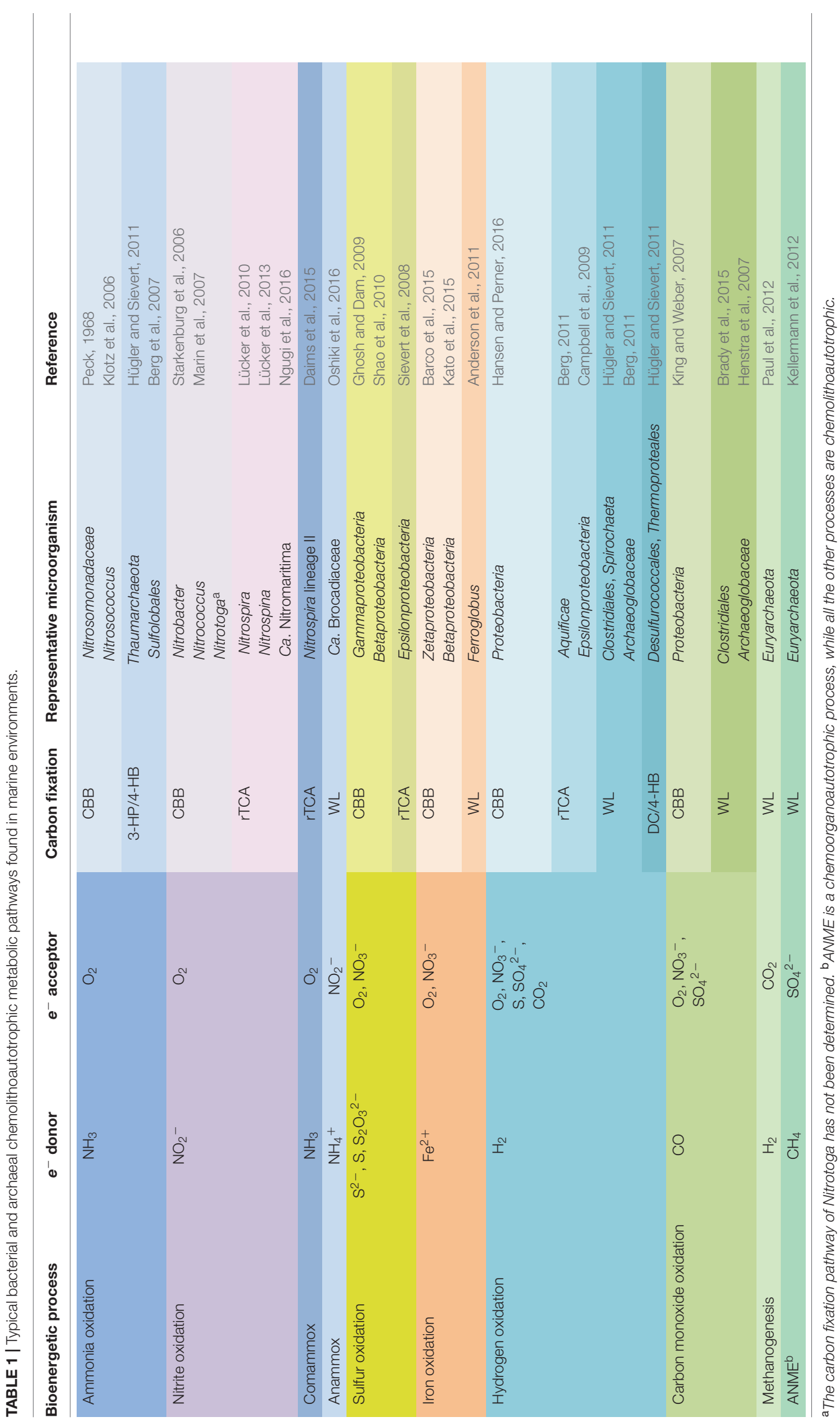




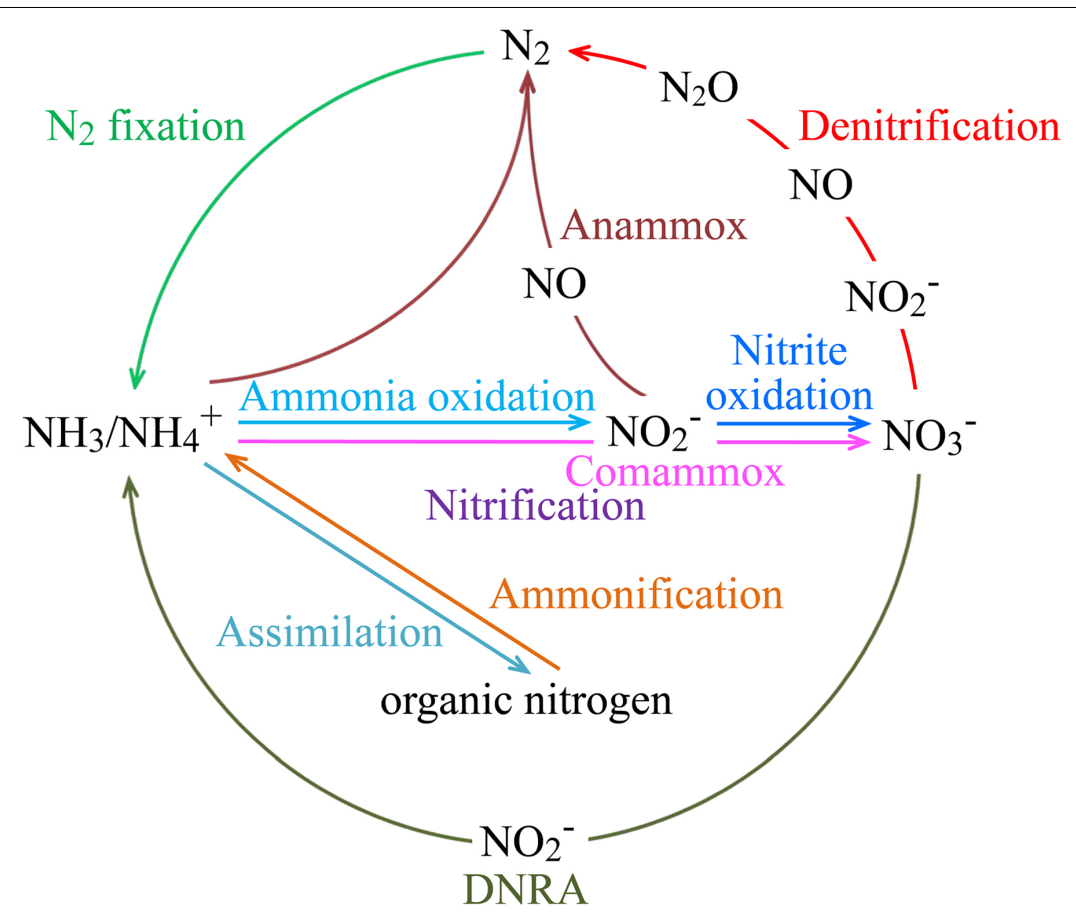

FIGURE 2 | Key processes of the marine nitrogen cycle. The processes of anammox and nitrification, which includes aerobic ammonia oxidation, nitrite oxidation, and comammox, are performed by chemolithoautotrophic microorganisms. Some other nitrogen transformation processes may also involve chemoautotrophic microorganisms, such as iron-oxidizing Zetaproteobacteria and methanogenic and anaerobic methane-oxidizing archaea for nitrogen fixation, and Gamma- and Epsilonproteobacteria for coupled sulfur oxidation and denitrification or DNRA. Abbreviations: Anammox, anaerobic ammonium oxidation; Comammox, complete ammonia oxidation to nitrate; DNRA, dissimilatory nitrate reduction to ammonium.

environmental adaptivity to low concentrations of ammonium and oxygen (Martens-Habbena et al., 2009; Hatzenpichler, 2012; Stahl and de la Torre, 2012; Horak et al., 2013; Offre et al., 2014; Qin et al., 2014; Corinaldesi, 2015). Two distinct marine ecotypes ("shallow" clade vs. "deep" clade) of AOA exist (Hatzenpichler, 2012; Luo et al., 2014), each may be adapted to distinct light and nutrient regimes of the water column. Some marine AOA may utilize ammonium instead of ammonia as the preferred energy substrate (Qin et al., 2014). Many AOA can also hydrolyze urea to utilize the ureolytic products (i.e., ammonia and $\mathrm{CO}_{2}$ ) for coupled ammonia oxidation and carbon fixation (Yakimov et al., 2011; AlonsoSáez et al., 2012; Connelly et al., 2014; Offre et al., 2014; Qin et al., 2014; Bayer et al., 2016; Tolar et al., 2016). Urea utilization thus represents a "short cut" and eco-energetically economic pathway between nitrification and carbon fixation in environmental AOA (Kirchman, 2012). Unlike AOB that use the Calvin-Benson-Bassham (CBB) cycle for carbon fixation, AOA use the most energetically efficient 3-hydroxypropionate/4hydroxybutyrate (3-HP/4-HB) cycle pathway for carbon fixation (Hügler and Sievert, 2011; Könneke et al., 2014). AOA contribute substantially to nitrification and dark carbon fixation even in hypoxic seawater, and their activities, albeit reduced, can still be detected under sulfidic conditions (Berg et al., 2015b). Moreover, some AOA may have the capacity of coping with phosphorus scarcity in marine environments. They harbor the pst gene that encodes for the high-affinity, high-activity phosphate ABC transporters (Dang et al., 2013b). Some AOA also produce inorganic phosphite and organic phosphorus compounds such as phosphonates, potentially serving as phosphorus storage mechanisms for metabolic sustainability under phosphorusstarving environmental conditions (Metcalf et al., 2012; Stahl and de la Torre, 2012; Dang et al., 2013b; Van Mooy et al., 2015). The production, processing, and uptake of these phosphorus compounds (in an oxidation state of +3 ) are highly energetically expensive, putatively indicating the importance of phosphorus to AOA in oligotrophic environments (Dang et al., 2013b). Alternatively, these ecophysiological traits may be evolutionary relics of ancient AOA, which experienced severe scarcity of phosphorus in the pre-anthropogenic ocean (Benitez-Nelson, 2015; Van Mooy et al., 2015). Furthermore, some environmental AOA assemblages were predicted to be mixotrophic (Dang et al., 2008b, 2010c) and certain AOA isolates are able to achieve maximum bioenergetic and growth efficiency with the availability of labile organic matter (Qin et al., 2014). The AOA mixotrophic potential has been challenged by the finding that organic matter is used by certain AOA isolates for non-enzymatic detoxification of hydrogen peroxide rather than as assimilable carbon source (Kim et al., 2016). However, a recent study indicates that the genomes of certain AOA do harbor key genes that encode peroxidases and catalases for coping with oxidative stress (Sauder et al., 2017). The diverse ecotypes and ecophysiological potentials of the numerically dominant AOA warrant further systematic investigations of their contributions to 
the ocean's carbon, nitrogen and phosphorus cycling and energy flux.

In marine environments, although $\mathrm{AOA}$ are ubiquitous and usually the dominant ammonia oxidizers, AOB may occupy particular niches and play important biogeochemical roles as well. Marine particles harbor abundant and active $\mathrm{AOB}$ (Karl et al., 1984). Most AOB in true marine environments are affiliated with the Nitrosospira genus, while Nitrosomonas AOB usually prevail in terrestrially impacted marine environments such as estuaries and coastal bays (Dang et al., 2010b). In stark contrast to this general $\mathrm{AOB}$ distribution pattern, nevertheless, marine particle-associated $\mathrm{AOB}$ are mainly affiliated with the Nitrosomonas genus (Karl et al., 1984; Phillips et al., 1999). Microbial hydrolysis of marine particleassociated organic nitrogenous compounds may produce high concentrations of $\mathrm{NH}_{4}{ }^{+}$and $\mathrm{NH}_{3}$ (Shanks and Trent, 1979; Gotschalk and Alldredge, 1989). Locally enriched ammonia may meet the need of those AOB (e.g., certain Nitrosomonas bacteria) that require high ammonia availability for energy transduction. Both Nitrosomonas and Nitrosospira AOB are affiliated with Betaproteobacteria. In marine environments, there exists another genus of $\mathrm{AOB}$, the Nitrosococcus that is affiliated with Gammaproteobacteria (Arp et al., 2007). Interestingly, Nitrosococcus AOB are found exclusively in marine environments and the optimal growth conditions of all known Nitrosococcus isolates in culture need at least $50 \mathrm{mM} \mathrm{NH}_{4}{ }^{+}$at pH 7.5 to 8.0 (Campbell et al., 2011; Wang et al., 2016). This implies that the niche of Nitrosococcus AOB may be mainly associated with estuarine and coastal sedimentary environments (Wang et al., 2016), where high concentrations of $\mathrm{NH}_{4}{ }^{+}$are usually found (e.g., Dang et al., 2008b, 2010b). It is also likely that the marine Nitrosococcus $\mathrm{AOB}$ are continuously under the environmental pressure of low energetic substrate availability, partially explaining their low abundance commonly found in seawater. The distinct distribution patterns of Nitrosomonas, Nitrosospira, Nitrosococcus, and AOA in the ocean may well reflect the different energy environments (e.g., the availability of $\mathrm{NH}_{3}$ ) they are dwelling.

To complete the nitrification process, nitrite produced by $\mathrm{AOA}$ and $\mathrm{AOB}$ needs to be further oxidized to nitrate, which is carried out by NOB. The oxidation of nitrite provides very low energy gain. Furthermore, the activity and growth of NOB may be limited by substrate availability in marine environments. These may be the major reasons that the abundance of NOB in most marine environments is usually very low (Füssel et al., 2012; Beman et al., 2013), except in the brine-seawater interface layer of the Red Sea where Nitrospina-like NOB may constitute up to onethird of the bacterial community (Ngugi et al., 2016). In contrast, AOA usually constitute a much higher fraction, up to or even greater than $40 \%$ of the total bacterial and archaeal community in the mesopelagic and bathypelagic zones of the ocean (Herndl et al., 2005; Kirchman et al., 2007; Bristow et al., 2015).

In spite of these bioenergetic and eco-energetic disadvantages, $\mathrm{NOB}$ are widespread in seawater and sediment environments. The strategy of NOB to overcome the constraint of low energy gain from nitrite oxidation is to produce high amounts of nitrite oxidoreductase, the key enzyme for nitrite oxidation
(Spieck et al., 2014). This channels more cellular metabolic energy to maintenance rather than to growth. Nitrite availability has recently been identified as a key factor driving niche differentiation in NOB (Nowka et al., 2015). In addition, to overcome the problem of low and varying nitrite concentrations in oxic seawater, some $\mathrm{NOB}$ can degrade certain simple dissolved organic nitrogen (DON) compounds such as urea and cyanate and reciprocally feed $\mathrm{AOB}$ with the degradation product $\mathrm{NH}_{3}$ for greater nitrite production (Koch et al., 2015; Palatinszky et al., 2015). Metagenomic screening has shown that ureaseand cyanase-harboring NOB may be prevalent in environments (Koch et al., 2015; Palatinszky et al., 2015). It is reasonable to hypothesize that metabolic collaborations between $\mathrm{NOB}$ and ammonia oxidizers (i.e., $\mathrm{AOB}$ and $\mathrm{AOA}$ ) in seawater may be facilitated in marine particle- and biofilm-associated microenvironments where cross-feeding is favored (Damashek et al., 2016; Dang and Lovell, 2016).

For more than a century, nitrification was accepted as a two-step biogeochemical process carried out sequentially by ammonia oxidizers and NOB. However, it was predicted that there exist some bacteria that can catalyze comammox, a process that is energetically feasible (Costa et al., 2006). Comammox bacteria have recently been discovered as unique sublineage II Nitrospira (Daims et al., 2015; van Kessel et al., 2015). Nitrospira are globally distributed, and similarly, functional gene biomarkers of comammox bacteria have been found to be prevalent in engineered and natural environments including marine sediments (Daims et al., 2015; van Kessel et al., 2015). The combination of the divided labors of ammonia oxidizers and NOB in the comammox bacteria bestows certain eco-energetic advantages, including facilitated acquisition of nitrite as an energy substrate and enhanced energy yield in terms of adenosine triphosphate (ATP) production (Costa et al., 2006; Daims et al., 2016). However, comammox also confers certain disadvantages to the bacteria. ATP is produced for catalytic purposes rather than for energy storage in cells (Pfeiffer and Schuster, 2005). The long metabolic pathway of comammox lowers the ATP production rate and thus the maximal growth rate the bacteria can achieve (Costa et al., 2006). The comammox process is predicted to be favored when ammonia and nitrite as energetic substrates are limiting and replenished slowly and when bacteria grow in clonal patches such as in biofilms (Costa et al., 2006). So far, no comammox bacteria have been found in marine waters (Kuypers, 2015). However, particles in seawater may present unique niches for comammox bacteria.

\section{The Unique Eco-energetic Mechanism of Chemolithoautotrophic Anammox Bacteria}

In oxygen-deficient and oxygen-depleted sediments and marine waters such as those occurring permanently in oceanic OMZs and seasonally in eutrophic coastal areas, microorganisms carrying out anammox and denitrification contribute to fixed nitrogen removal (Devol, 2015). Anammox bacteria employ the redox reaction of coupled nitrite reduction and ammonium oxidation for energy transduction to fix carbon (Kartal et al., 2013; 
Oshiki et al., 2016), while bacterial and archaeal denitrifiers are usually heterotrophs that use organic matter as electron donors for stepwise reduction of nitrate, nitrite, $\mathrm{NO}$, and $\mathrm{N}_{2} \mathrm{O}$ to produce $\mathrm{N}_{2}$ (Carolan et al., 2015; Devol, 2015). Anammox bacteria harbor anammoxosomes, unique organelles functionally analogous to eukaryotic mitochondria to perform the energetic reaction (van Niftrik and Jetten, 2012; Jogler, 2014). Anammox bacteria are affiliated with a narrow bacterial clade, the Candidatus Brocadiales order of Planctomycetes (Kartal et al., 2013). In addition to physiological specialization and phylogenetic segregation, niche separation is also prevalent in anammox bacteria. Ca. Scalindua mainly occur in marine environments and all the other anammox bacterial genera are adapted to low-salinity habitats (Kartal et al., 2013). Estuaries are an exception where $\mathrm{Ca}$. Scalindua and some freshwater anammox bacteria may both exist (Dang et al., 2010a, 2013c). In contrast, marine denitrifiers are common in Bacteria and Archaea, a phenomenon likely being facilitated by horizontal gene transfer for denitrifying trait spreading (Jones et al., 2008). Furthermore, most denitrifiers are facultative anaerobes and can rapidly switch among different energetic pathways in response to changing environmental conditions (Dang and Jiao, 2014), while anammox bacteria are obligate anaerobes and they may prefer stable environmental conditions.

As anammox bacteria and denitrifying microorganisms occupy similar environments, they may compete for nitrate and nitrite (as electron acceptors) for energy transduction. The bioavailability of organic carbon and organic matter stoichiometry may be key factors determining the relative contributions of anammox and denitrification to fixed nitrogen removal in the ocean (Thamdrup and Dalsgaard, 2002; Engström et al., 2005; Babbin et al., 2014; Chang et al., 2014; Babbin et al., 2016). Most organic compounds that are microbiologically utilizable as electron donors can be more easily oxidized and thus more energy-favorable than ammonium. This energetic difference influences the distribution of the anammox bacteria and denitrifiers in the ocean and their relative contributions to the marine nitrogen and carbon cycling (Dang et al., 2009b, 2010a; Ulloa et al., 2012). In suboxic and anoxic environments that are rich in organic matter such as some eutrophic coastal waters and sediments, heterotrophic denitrifiers usually outperform chemolithoautotrophic anammox bacteria for fixed nitrogen removal, while in certain oceanic OMZs the contribution of anammox bacteria may match or even outperform that of the heterotrophic denitrifiers (Ward et al., 2009; Ulloa et al., 2012). Similarly, organicpoor deep-sea sediments usually favor anammox activity over denitrification (Jaeschke et al., 2010; Devol, 2015). However, the influence of organic carbon on the partitioning of nitrogen loss between anammox and denitrification may be more complicated than previously thought. It was found recently that organic matter enrichment may stimulate dissimilatory nitrate reduction to ammonium (DNRA), competing against denitrification for nitrate acquisition (Brin et al., 2017). The complex microbial nitrogen transformation processes and their distinctly different responses to specific suboxic and anoxic marine environments constitute an obstacle to a simple and predictive understanding of the microbe-environment interactions.

\section{ECO-ENERGETIC RESPONSES OF NITROGEN-CYCLING CHEMOLITHOAUTOTROPHS TO GLOBAL CHANGE IMPACTS}

Chemolithoautotrophic microorganisms have been playing critical roles in shaping the Earth's environment and planetary evolution (Fuchs, 2011; Martin et al., 2014). Although photoautotrophs (i.e., cyanobacteria, algae, and plants) are the most dominant carbon fixers on the surface layer of land and ocean, chemolithoautotrophic microorganisms have been carrying out carbon fixation long before the advent of oxygenic photosynthetic organisms (Fuchs, 2011; Braakman and Smith, 2012; Jelen et al., 2016). Some chemolithoautotrophs were probably among the first organisms on earth and have played a key role in driving the transition of earth from its primordial inorganic state to a state rich in biogenic organic matter. They may have made substantial impacts on the geochemical condition and redox status of the primitive Earth, leading to the origination and evolution of the planet ecosystems and biogeochemical cycles.

Anthropogenic activities have significantly changed the Earth's environments and ecosystems as well (Duarte, 2014; Brondizio et al., 2016). Rapid increase in $\mathrm{CO}_{2}$ emission as a result of fossil fuel consumption has led to various environmental problems such as global warming, ocean acidification, and ocean hypoxia. Carbon perturbation induced by ongoing global change is further compounded by other harmful human activities such as environmental pollution and eutrophication (Bijma et al., 2013). How these anthropogenic environmental disturbances influence the eco-energetics and biogeochemical functions of the marine microbiota warrants in-depth examinations, particularly for the chemolithoautotrophic microorganisms that play important roles in carbon fixation and carbon sequestration of the ocean.

\section{Chemolithoautotrophic Responses to Global Warming}

Temperature is an important environmental factor that influences microbial ecophysiology and biogeochemical functioning in multiple and profound ways. For example, the permeability of proton across cytoplasmic membranes, which plays a critical role in microbial bioenergetic processes, increases with environmental temperature (Tolner et al., 1997; Berry, 2002). Proton leakage lowers the microbial bioenergetic efficiency. Therefore, microorganisms continuously monitor surrounding temperature and abrupt temperature changes usually induce rapid microbial stress responses (Schumann, 2009). It was predicted that a $1^{\circ} \mathrm{C}$ increase of seawater temperature in the bathypelagic ocean may cause a $55 \%$ increase of heterotrophic production by the in situ bacterial and archaeal community (Lønborg et al., 2016). However, autotrophic and heterotrophic microorganisms may respond to ocean warming 
differently, leading to changes in the ocean's metabolic balance (Lønborg et al., 2016).

Nitrogenous nutrient scarcity tends to limit primary production of the phytoplankton communities throughout much of the low-latitude surface ocean (Moore et al., 2013). Eco-energetically, chemolithoautotrophic nitrogen-cycling microorganisms carry out dissimilatory transformations of nitrogenous compounds, resulting in the compositional changes and/or loss of nitrogenous nutrients from environments (Stein and Klotz, 2016). They contribute to marine carbon cycling not only by direct carbon fixation but also by their control on the speciation, concentration, and distribution of nitrogenous nutrients in the ocean, thus influencing the composition, structure, activity, and spatiotemporal dynamics of the photosynthetic communities and their primary productivity. The interactions of nitrogen-cycling microorganisms with photosynthetic communities via the linkage of nutrients are highly complex and influenced by diverse factors. For example, the deep ocean is usually rich in nitrate, resulted mainly from the activities of chemolithoautotrophic ammonia- and nitriteoxidizers. However, the deep ocean is devoid of sun light and thus phototrophic activities. This creates a spatial decoupling of nutrients with solar light energy, limiting substantially the primary productivity and carbon sequestration capacity of the ocean. With the impact of global warming, the surface ocean is becoming warmer and more stratified, aggravating the spatial decoupling of deep ocean nutrients and surface ocean photosynthetic $\mathrm{CO}_{2}$ fixation.

Aerobic ammonia oxidation by $\mathrm{AOA}$ has been found as one of the highest energy-yielding chemolithotrophic processes in high temperature environments such as hot springs (Dodsworth et al., 2012; Hatzenpichler, 2012). Physiological, genomic, and phylogenetic analyses suggest that the ancestor of AOA was thermophilic and a number of studies support this inference by showing the prevalence of $\mathrm{AOA}$ in terrestrial hot spring and coastal and deep-sea hydrothermal vent environments (Hatzenpichler, 2012; Stahl and de la Torre, 2012; Wang L. et al., 2015). The ubiquity of abundant AOA in mesopelagic and bathypelagic seawater and deep-sea sediments suggests that their mesophilic and psychrophilic physiology may be the result of secondary adaptations (Hatzenpichler, 2012; Stahl and de la Torre, 2012). On the contrary, AOB may have a mesophilic origin. A microcosm experiment showed that the composition of soil AOB usually changes very little with increasing temperature, while the abundance and ammonia oxidation potential activity of certain AOA phylotypes increase significantly with increasing temperature (Tourna et al., 2008). In line with this, a recent study showed that the biochemical processes of ammonia oxidation may be thermodynamically different between soil AOA and AOB, with AOA having a significantly higher minimum temperature than AOB for ammonia-oxidizing activity (Taylor et al., 2017). Although it is unknown if marine AOA and AOB bear a similar thermodynamic difference, temperature was putatively identified as a key environmental factor affecting the composition and distribution of the AOA assemblages in sediments of the South China Sea, a large marginal sea in the subtropical and tropical Pacific Ocean (Dang et al., 2013b). Does this mean that the marine AOA may be more responsive than $\mathrm{AOB}$ to ocean warming? The polar ecosystems are currently facing strong global warming effects (Schofield et al., 2010; Spielhagen et al., 2011). However, a recent investigation in western coastal Arctic seawater shows that nitrification rates, likely contributed mainly by AOA, are resistant to short-term temperature elevations (Baer et al., 2014). A common trend of the warming effects on the diverse marine nitrifying microbiota cannot be concluded yet. How and to what extent elevated seawater temperatures caused by global warming may directly affect the ecophysiology of marine AOB, $\mathrm{AOA}$, and NOB are still difficult to predict.

In addition to the direct effects, global warming may also exert certain indirect effects on the marine nitrifying microbiota and their eco-energetic and carbon-fixing activities. Global warming causes ocean stratification that weakens the vertical mixing of seawater and makes surface water of the open oceans to be more oligotrophic. This effect may lower phytoplankton primary productivity and thus the export of particulate organic matter (POM) from the surface ocean to the deep ocean and sediments (Bijma et al., 2013; Turner, 2015). Marine particles and sinking phytoplankton aggregates are the hotspots of extracellular enzyme activities, contributing to microbial degradation of POM polymeric organic matter and release of nutrients and energy substrates such as ammonium, phosphate and labile DOC in the middle and deep waters of the ocean (Azam and Malfatti, 2007; Wright et al., 2012; Ploug and Bergkvist, 2015; Dang and Lovell, 2016; Krupke et al., 2016). Certain studies have suggested enhanced nitrification activities in marine waters that are rich in particles and phytoplankton aggregates (Karl et al., 1984; Klawonn et al., 2015a; Damashek et al., 2016). Diminished biological pump (BP) function caused by the global warming effects reduces not only the ocean's carbon sequestration capacity but also the nutrient replenishment rate in the interior of the ocean. Diminished ammonium supply due to weakened BP exports may lead to reductions of the nitrifiers' activities such as nitrate production and carbon fixation in the marine mesopelagic and bathypelagic zones.

A number of studies have shown that the anammox bacteria are well adapted to low-temperature environments such as deep-sea and polar region sediments (Rysgaard et al., 2004; Jaeschke et al., 2010; Russ et al., 2013; Canion et al., 2014a,b; Shao et al., 2014; Sonthiphand et al., 2014). Anammox bacteria can alter the composition of their cell membranes and thus enhance the membrane fluidity by increasing the content of short chain ladderane fatty acids in response to low-temperature conditions (Rattray, 2008). In cold environments, anammox bacteria are found to carry out psychrophilic anammox process, while denitrifying bacteria usually carry out psychrotrophic nitrogen removal process (Rysgaard et al., 2004; Canion et al., 2014a,b). Colder temperature thus may be an important environmental factor that favors anammox over denitrification in deep-ocean and polar sea sedimentary environments (Rysgaard et al., 2004; Canion et al., 2014a,b; Shao et al., 2014). The different temperature adaptations between anammox bacteria and denitrifiers suggest that increased temperatures caused by global warming may favor denitrification over anammox in cold marine environments. However, in a recent study, the 
psychrophilic physiology of anammox bacteria could not be verified and anammox and denitrification were found to have similar temperature responses, which are not influenced by warming in temperate coastal environments (Brin et al., 2017). Another study found little changes of community structure and activity rate of anammox bacteria and denitrifiers in response to increased temperatures, suggesting both microbial groups may be ecophysiologically tolerant to climate warming disturbances (Canion et al., 2014b). More systematic ecology studies covering broader environmental conditions are necessary for revealing the true ecophysiological characteristics of the marine anammox bacteria and denitrifiers.

The anammox and denitrification microbial assemblages may be influenced by global warming via its indirect effects. Although both denitrification and anammox activities may be enhanced by marine particles and phytoplankton aggregates, seawater anammox bacteria are frequently found as free-living microorganisms except in a few cases (Woebken et al., 2007; Ganesh et al., 2015; Stief et al., 2016). Dissolved organic matter (DOM) and POM usually stimulate denitrification rates by providing the necessary energy and carbon sources for the denitrifiers (Canion et al., 2014b; Chang et al., 2014; Babbin et al., 2016), while the chemolithoautotrophic anammox bacteria rely less on organic matter for energy and material metabolisms. Therefore, reductions in POM flux and DOC availability induced by global warming may affect more negatively on denitrification than on anammox in the ocean's mesopelagic and bathypelagic zones and the deep-sea sediments (Canion et al., 2014b). However, in temperate estuarine and coastal sediment environments, a recent study showed that the role of organic matter in altering nitrogen removal partitioning between anammox and denitrification cannot be verified (Brin et al., 2017).

The controversial effects of temperature and organic matter on the activities of anammox and denitrification indicate the complexity of the microbial responses to the global warming effects. Microbial communities in different marine environments may have developed different ecophysiologies and habitat adaptivities. The key limiting environmental factors that control the anammox and denitrifying activities in different environments may be different as well. For example, microbial assemblages in temperate estuarine and coastal environments experience obvious seasonal changes in temperature, nutrients and various sources of organic matter inputs. In addition, estuarine and coastal environments usually experience eutrophication and pollutions. The microbiota here may have developed adaptations to these varying factors. Moreover, the different microbial nitrogen transforming processes may also be influenced by the scarcity of various trace metals as enzyme cofactors and/or by the toxicity of diverse heavy metals to enzymes, a critical scientific question in microbial eco-energetics that is not yet clearly solved (Klotz and Stein, 2008; Simon and Klotz, 2013; Glass et al., 2015; Löscher et al., 2016). This implies that some environmental conditions, other than temperature and organic matter, may be the most important factors controlling the denitrification and anammox activities in certain marine environments. Furthermore, complex interactions among the different microbial functional groups and between microorganisms and other organisms in the ecosystems may all influence the outcomes of the global warming effects. For example, addition of extra DOM or POM may stimulate the DNRA activity rather than the denitrification activity (Brin et al., 2017). The effects of protozoan grazing and viral lysis on the partitioning of nitrogen loss between denitrification and anammox in marine environments are not resolved, either (Löscher et al., 2016). The high degrees of complexity and uncertainty indicate that there is the need of more systematic investigations for a comprehensive and accurate understanding of the responses of marine anammox and denitrifying microorganisms to the impacts of ocean warming.

\section{Chemolithoautotrophic Responses to Ocean Acidification}

Increased anthropogenic $\mathrm{CO}_{2}$ emission causes not only global warming, but also increased partial pressure of $\mathrm{CO}_{2}\left(p \mathrm{CO}_{2}\right)$ and hence decreased $\mathrm{pH}$ in seawater. The most significant drops of $\mathrm{pH}$ are usually associated with estuarine and coastal seawater, caused additionally by terrestrial, anthropogenic, mixing and upwelling inputs of nutrients and organic matter that lead to enhanced primary production and microbial respiration (Cai et al., 2011; Lui et al., 2015). Increased atmospheric deposition of nitrogen and sulfur in coastal regions resulting from fossil fuel combustion and agricultural fertilizer application also lowers seawater pH (Doney et al., 2007; Hagens et al., 2014). Acidification may influence the ocean's primary productivity and carbon sequestration capacity (Doney et al., 2009). Acidification also changes the equilibrium of the ocean's carbonate chemistry system, leading to stresses and damages to certain sensitive ecosystems such as the shallow coral reefs (Andersson and Gledhill, 2013; O'Brien et al., 2016). Ocean acidification may reduce marine biodiversity and fisheries as well, due to acidification-induced animal physiological stresses and/or acidification-induced changes in the ecosystem's trophic transfer efficiency (Widdicombe and Spicer, 2008; Branch et al., 2013; Cripps et al., 2016; van Leeuwen et al., 2016).

Ocean acidification may exert significant impacts on marine biogeochemical cycles. For example, microbial photosynthesis and nitrogen fixation have been found to be enhanced under acidification conditions in the surface ocean, which may be related directly to enhanced inorganic carbon assimilation due to increased seawater $p \mathrm{CO}_{2}$ (O'Brien et al., 2016). However, ocean acidification exerts a negative impact on the chemolithoautotrophic ammonia oxidation process. Ocean acidification changes the seawater $\mathrm{NH}_{3} / \mathrm{NH}_{4}{ }^{+}$equilibrium by ionizing more ammonia molecules to form ammonium cations. A $0.3 \mathrm{pH}$ decrease projected to happen by the year 2100 (Caldeira and Wickett, 2005) may cause a 50\% decrease of the seawater $\mathrm{NH}_{3}$ concentration (Zeebe and Wolf-Gladrow, 2001). Studies have shown that this shift in $\mathrm{NH}_{3} / \mathrm{NH}_{4}{ }^{+}$equilibrium may directly reduce the ocean's ammonia oxidation rate (Beman et al., 2011). Although marine sediments have certain buffering effect against porewater $\mathrm{pH}$ changes (Kitidis et al., 2011), decreases of benthic nitrification 
rate have also been reported in some investigations (Braeckman et al., 2014). However, the change of nitrite oxidation activity in response to ocean acidification may be quite different from that of ammonia oxidation activity. The response of the two-step nitrification process to ocean acidification may be more complicated that previous thought. A recent study showed that the nitrite oxidation rates of coastal seawater correlate positively with $\left[\mathrm{H}^{+}\right]$and thus negatively with $\mathrm{pH}$ (Heiss and Fulweiler, 2016). Currently it is not clear if this phenomenon is common in the world oceans, nor is known about the mechanism for this NOB response.

Furthermore, global warming may exert a compound effect along with ocean acidification on the change of marine nitrification. It was found that high temperature in summer had an inhibitory effect on the activity and growth of NOB, leading to the decoupling of ammonia oxidation and nitrite oxidation and thus the accumulation of nitrite in seawater (Bristow et al., 2015; Schaefer and Hollibaugh, 2017). Some NOB such as Nitrotoga spp. prefer environments with a slightly acidic $\mathrm{pH}$ and lowtemperatures $\left(<20^{\circ} \mathrm{C}\right)$ in physiological experiments (Hüpeden et al., 2016). Global warming increases the temperature of both the surface ocean and the ocean's interior (Masuda et al., 2010; Mora et al., 2013; Levin and Le Bris, 2015), thus it may negatively influence the rate of nitrite oxidation in certain environments of the ocean. Under the combined influences of ocean acidification and global warming, the chemical composition of the ocean's nitrogenous nutrient reservoir may be altered. It is well known that nitrate is the primary inorganic nitrogen source for marine diatoms, which contribute substantially to the BP-mediated particulate organic carbon (POC) export and storage in the ocean's interior (Bowler et al., 2010; Beman et al., 2011; Diner et al., 2016). On the contrary, marine dinoflagellates were found to be favored by ammonium, which also enhances algal bloom formation and toxin production (Leong et al., 2004; HattenrathLehmann et al., 2015). The lowered nitrate pool due to ocean acidification- and warming-induced decrease of nitrification may lower diatoms-mediated primary production and POC-mediated carbon sequestration of the ocean but increase the incidences of harmful algal blooms by dinoflagellates.

Although certain soil AOB and AOA strains such as $\mathrm{Ca}$. Nitrosotalea devanaterra have been found to be obligate acidophiles (Hayatsu, 1993; Lehtovirta-Morley et al., 2016), it is doubtable that the majority of the marine $\mathrm{AOB}$ and AOA are acidophiles because the seawater $\mathrm{pH}$ is usually above 7 . The long-term lack of acidic conditions makes it difficult for marine $\mathrm{AOB}$ and $\mathrm{AOA}$ to evolve genetic and physiological mechanisms to become acidophilic. However, not all the bacterial and archaeal ammonia oxidizers respond to ocean acidification in the same way. Ocean acidification may change the composition of the ammonia-oxidizing communities, in which urease-harboring $\mathrm{AOA}$ and $\mathrm{AOB}$ may gain more importance as they can use urea as a source of ammonia and $\mathrm{CO}_{2}$ for both energy transduction and carbon fixation (Koper et al., 2004; Klotz et al., 2006; Kirchman, 2012; Bowen et al., 2013). Urea is the most abundant chemical species of labile low-molecular-weight DON in the ocean (Solomon et al., 2010). Rapid autochthonous production by bacteria, algae, protists, and animals (e.g., zooplankton, mollusks, crustaceans, fish, and mammals) and various allochthonous inputs such as from agricultural fertilizers make urea an important constituent of the marine nitrogen cycle (Berman and Bronk, 2003; Glibert et al., 2006; Solomon et al., 2010). The urea molecule is uncharged and its chemistry does not change with $\mathrm{pH}$. Urea is prevalent in seawater and sediment porewater (Glibert et al., 2006; Solomon et al., 2010), likely serving as a preferred and important nitrogen source for ureolytic ammonia oxidizers under acidified conditions (PommereningRöser and Koops, 2005; Lu and Jia, 2013). Indeed, ureolytic AOA have been found as the major ammonia oxidizers contributing significantly to the nitrification activity in certain marine environments (Alonso-Sáez et al., 2012; Tolar et al., 2016). Urea as an alternative substrate source for microbial ammonia oxidation may compensate, to currently unknown degrees, for the reduction of the marine nitrification activities caused by ocean acidification. In addition, some studies showed that the nitrite oxidation rates are greater than the ammonia oxidation rates in coastal seawater (Heiss and Fulweiler, 2016). Some sources of nitrite, other than that provided by in situ ammonia oxidation, may provide extra nitrite for the activity of NOB. Seawater cyanate may be used by NOB for "reciprocal feeding" of ammonia oxidizers to obtain extra nitrite (Palatinszky et al., 2015; Heiss and Fulweiler, 2016). However, currently the quantitative contributions of ureolytic ammonia oxidizers and cyanate-degrading $\mathrm{NOB}$ to nitrification in the global ocean under acidification conditions have not been in-depth and systematically investigated.

Ocean acidification may enhance anammox activity, partially resulting from increased ammonium concentrations due to the shift of the $\mathrm{NH}_{3} / \mathrm{NH}_{4}{ }^{+}$equilibrium under acidification conditions (Widdicombe and Needham, 2007; Gazeau et al., 2014; Tait et al., 2014). Ocean acidification may enhance the activity of denitrification as well, because the $\mathrm{NO}_{3}{ }^{-}, \mathrm{NO}_{2}{ }^{-}$, and $\mathrm{NO}$ reductases are more active at neutral or lower $\mathrm{pH}$ (Richardson et al., 2009). Therefore, it is likely that fixed nitrogen loss from the ocean will increase due to ocean acidification. Furthermore, ocean acidification may cause an increase of greenhouse gas $\mathrm{N}_{2} \mathrm{O}$ production as $\mathrm{N}_{2} \mathrm{O}$ reductase is sensitive to $\mathrm{pH}$ and less active at $\mathrm{pH}<7$ (Richardson et al., 2009). A recent study suggests that low $\mathrm{pH}$ interferes with the $\mathrm{N}_{2} \mathrm{O}$ reductase assembly, putatively revealing a molecular mechanism of the acidification effect on $\mathrm{N}_{2} \mathrm{O}$ dynamics (Liu et al., 2014). Acidification may increase $\mathrm{N}_{2} \mathrm{O}$ production by aquatic ammoniaoxidizers, as well (Frame et al., 2017). Seawater $\mathrm{N}_{2} \mathrm{O}$ production is further compounded by many macroscopic processes of the ocean, such as vertical mixing and upwelling (Tseng et al., 2016). In summary, ocean acidification may cause altered (likely decreased) nitrification, increased $\mathrm{N}_{2} \mathrm{O}$ emission and increased loss of nitrogenous nutrients via enhanced denitrification and anammox, among many other significantly altered biogeochemical processes in the ocean. It is necessary to develop a mechanistic and quantitative understanding of the various marine nitrogen-cycling processes and the ocean acidification effects, which are fundamentally important for better modeling and predication of the behavior and function of the future marine nitrogen and carbon cycles. 


\section{Chemolithoautotrophic Responses to Ocean Eutrophication and Deoxygenation}

The trophic and oxygenation states are two critical and interconnected factors that have significant influences on the ecological processes and biogeochemical functions of the ocean's ecosystems. Anthropogenic eutrophication and upwelling are the major contributors to coastal hypoxia and anoxia, which may be additionally enhanced by incoming offshore seawater in certain marginal seas (Lui et al., 2014). Coastal eutrophication is predicted to increase, due to continuing increase of human activities (Doney, 2010; Nogales et al., 2011; Statham, 2012; Bijma et al., 2013). Under the impact of ongoing global change, the duration and intensity of most of the large-scale upwelling systems are predicted to increase as well (Sydeman et al., 2014; Wang D. et al., 2015). Global warming exacerbates the frequency, extent and impacts of coastal "dead zones," which usually occur during warm seasons. The oceanic OMZs will also intensify and expand due to warming-induced oxygen solubility reduction and seawater stratification (Keeling et al., 2010; Wright et al., 2012). Therefore, oceanic OMZs and coastal hypoxia and anoxia will undoubtedly exacerbate in the future. These situations may alter the major metabolic pathways and functional services of the affected ecosystems.

Hypoxic and anoxic environments may facilitate microbial nitrogen fixation (Zhou et al., 2016). Under $\mathrm{O}_{2}$-rich environments, bacterial nitrogen acquisition through nitrogen fixation is eco-energetically less favorable than assimilatory nitrate uptake (Eichner et al., 2014; Jiang et al., 2015). However, in hypoxic environments such as the marine OMZs, nitrogen fixation may be eco-energetically more favorable and less inhibited by high nitrate concentrations (Großkopf and Laroche, 2012). Because most of the diazotrophs in the aphotic marine hypoxic and anoxic environments are heterotrophs, the availability of metabolizable organic substrates as energy sources is an important factor influencing the abundance and activity of the in situ diazotrophs. Alternatively, chemolithoautotrophic ANME-2c archaea may contribute substantially to nitrogen fixation in methane-rich environments (Pernthaler et al., 2008; Dang et al., 2009a; Dekas et al., 2009; Miyazaki et al., 2009). Furthermore, the diazotrophic abundance and activity may also be controlled by the availability of phosphate and/or iron, which may vary in different marine environments (Moore et al., 2013; Dang and Lovell, 2016). Diazotrophic microorganisms and activity have been confirmed in studied marine hypoxic and anoxic environments (Fernandez et al., 2011; Hamersley et al., 2011; Jayakumar et al., 2012; Loescher et al., 2014). The study of non-cyanobacterial diazotrophic contribution to the ocean's reactive nitrogen pool constitutes a new research paradigm of marine nitrogen cycling (Bombar et al., 2016). Breakthroughs in this field are indubitably instrumental to developing better understandings of the marine carbon cycle and its interactions with global change.

Although nitrogen fixation may be enhanced in hypoxic and suboxic seawater, loss of fixed nitrogen via denitrification and anammox is more eco-energetically favorable and thus nitrogen loss is the major microbial process in these environments (Lam and Kuypers, 2011). It has been estimated that oceanic OMZ seawater accounts for one third or more of fixed nitrogen loss on a global scale (Canfield et al., 2010b). Under hypoxic and anoxic conditions, enhanced availability of reduced inorganic chemicals such as ammonia/ammonium and sulfide as energy sources facilitates microbial carbon fixation that is coupled to nitrogen and sulfur cycling processes, including chemolithoautotrophic ammonia oxidation, nitrite oxidation, sulfur oxidation, and anammox. Some of these microbial processes are intensified particularly at or near the oxic-anoxic interfaces in the water columns (Füssel et al., 2012; Capone and Hutchins, 2013). These processes may help to restore the nitrogen balance by removal of excess nitrogen originated from riverine and terrestrial inputs in eutrophic estuarine and coastal waters. However, they may aggravate the scarcity of nitrogenous nutrients and exert further limitation on the ocean's capacity of primary productivity and carbon sequestration in oceanic waters. A recent study has found that $\mathrm{AOA}$ and $\mathrm{NOB}$ in OMZs have high affinities for oxygen and nitrification (even at $5 \mathrm{nM} \mathrm{O}_{2}$ ) may control fixed nitrogen loss that is subsequently performed by denitrification and anammox (Bristow et al., 2016).

The scarcity of fixed nitrogen limits primary production and BP-mediated carbon sequestration in vast regions of the ocean (Moore et al., 2013). To make the situation even worse, the current fixed nitrogen pool of the ocean may be unbalanced and dwindling, caused by nitrogen loss via denitrification and anammox being significantly greater than nitrogen gain via nitrogen fixation (Codispoti et al., 2001; Mahaffey et al., 2005; Codispoti, 2007). Although uncertainties and debates remain about the conundrum of this imbalance (Gruber and Galloway, 2008; Canfield et al., 2010a; Zehr and Kudela, 2011; Großkopf et al., 2012; Voss et al., 2013; Devol, 2015; Klawonn et al., 2015b; Zhou et al., 2016), enhanced nitrogen loss by denitrification and anammox as a result of aggravated hypoxia, anoxia and acidification in coastal seas and oceanic OMZs may indeed diminish the marine fixed nitrogen reservoir under the impacts of increasing anthropogenic activities and global warming. This diminishment may constitute a positive feedback mechanism that speeds up global change by further limiting the ocean's carbon sequestration capacity.

The marine hypoxic and anoxic environments are also the hotspots for the production of biogenic greenhouse gases such as $\mathrm{N}_{2} \mathrm{O}, \mathrm{CH}_{4}$, and occasional $\mathrm{H}_{2} \mathrm{~S}$ (Naqvi et al., 2010; Wright et al., 2012; Capone and Hutchins, 2013; Carolan et al., 2015; Murray et al., 2015; Kock et al., 2016). $\mathrm{N}_{2} \mathrm{O}$ is produced by many microbial processes and it is also the precursor of $\mathrm{NO}$ radicals that cause ozone destruction in the stratosphere (Carpenter et al., 2012; Schreiber et al., 2012; Voss et al., 2013; Mellbye et al., 2016). Hypoxic and anoxic environments that are rich in labile organic matter facilitate heterotrophic denitrification and the production of $\mathrm{N}_{2} \mathrm{O}$ as a metabolic intermediate (Gilly et al., 2013; Townsend-Small et al., 2014; Babbin et al., 2015; Castro-González and Farías, 2015). 
Autotrophic denitrification that couples denitrification with anaerobic chemolithoautotrophic sulfide oxidation also contributes to fixed nitrogen removal and $\mathrm{N}_{2} \mathrm{O}$ production in these environments (Shao et al., 2010; Ulloa et al., 2012). Anammox bacteria may produce $\mathrm{N}_{2} \mathrm{O}$ as well, via enzymatic $\mathrm{NO}$ detoxification (Kartal et al., 2007). $\mathrm{N}_{2} \mathrm{O}$ is also produced by AOA and $\mathrm{AOB}$, though the detailed mechanisms involved in these two groups of aerobic microorganisms may be quite different (Kozlowski et al., 2016). Hypoxic conditions strongly stimulate AOB $\mathrm{N}_{2} \mathrm{O}$ production via the enzymatic nitrifier denitrification process, while $\mathrm{N}_{2} \mathrm{O}$ production in AOA may result from abiotic reactions (Codispoti, 2010; Zhu et al., 2013; Kozlowski et al., 2016).

Submicromolar $\mathrm{O}_{2}$ has been found to reversibly suppress anammox and denitrification, likely at the enzymatic level (Dalsgaard et al., 2014). Due to intracellular anammoxosomes, anammox bacteria may be more resistant to $\mathrm{O}_{2}$ suppression than denitrifying bacteria (Dalsgaard et al., 2014). Relative to anammox, denitrification is likely to be a more important $\mathrm{N}_{2} \mathrm{O}$ production process in hypoxic environments. It has also been found that sulfide, which accumulates in extremely anoxic environments or exists cryptically under hypoxic conditions (Canfield et al., 2010b; Glaubitz et al., 2013), strongly stimulates denitrifying $\mathrm{N}_{2} \mathrm{O}$ production without affecting the anammox process (Dalsgaard et al., 2014). Hypoxic and anoxic conditions are usually accompanied by environmental acidification, which may cause increased denitrifier $\mathrm{N}_{2} \mathrm{O}$ production (see above "Chemolithoautotrophic Responses to Ocean Acidification" section). Marine hypoxic and anoxic conditions influence the speciation and abundance of many trace elements and heavy metals, which may also influence the microbial production of greenhouse gasses via influencing the synthesis and activity of the involved enzymes (Glass and Orphan, 2012). Furthermore, many denitrifiers harbor truncated denitrifying pathways lacking the gene of $\mathrm{N}_{2} \mathrm{O}$ reductase for reducing $\mathrm{N}_{2} \mathrm{O}$ to $\mathrm{N}_{2}$, contributing to $\mathrm{N}_{2} \mathrm{O}$ production and accumulation in the environments (Jones et al., 2008; Richardson et al., 2009; Graf et al., 2014). Although shorter pathways of energy metabolism lowers ATP yield, they increase the ATP production rate and thus the maximal growth rate of the denitrifiers (Costa et al., 2006; Jones et al., 2008; Simon and Klotz, 2013), providing an eco-energetic advantage in environments rich in labile organic matter and nitrate.

The diverse microbial $\mathrm{N}_{2} \mathrm{O}$ production pathways and environmental controlling factors dictate the dynamics of the marine $\mathrm{N}_{2} \mathrm{O}$ reservoir. With the increasing expansion of both the oceanic OMZs and coastal hypoxic and anoxic water bodies, it is reasonable to predict that the microbial processes in these environments may contribute more to the production of $\mathrm{N}_{2} \mathrm{O}$. This may constitute a positive feedback on global change. Currently, the relative contributions of the different microbial $\mathrm{N}_{2} \mathrm{O}$ production processes to the marine $\mathrm{N}_{2} \mathrm{O}$ reservoir and dynamics is still not reliably solved, particularly at the regional and global scales. This situation may be tackled by future investigations and modeling, in which the incorporation of the microbial eco-energetic constraints may be helpful.

\section{Chemolithoautotrophic Responses to Environmental Trace Element Variations and Heavy Metal Pollutions}

Ecosystem energy flow interconnects with the interweaved biogeochemical cycles of carbon, nitrogen, phosphorus, sulfur, and many other elements such as biological trace metals (Falkowski et al., 2008; Jelen et al., 2016). Many of the microbial energetic processes are catalyzed by metalloenzymes (Nitschke et al., 2013). Although exergonic bioenergetic reactions are thermodynamically favorable, they are usually hindered kinetically by high activation barriers and need enzymes to speed up (Nitschke et al., 2013). Activities of metalloenzymes rely on various redox-active metal cofactors. Due to their plasticity in adopting different oxidation states and coordination environments in diverse enzyme molecules, redox-sensitive transition metals such as $\mathrm{Fe}, \mathrm{Ni}, \mathrm{Cu}, \mathrm{Zn}, \mathrm{Co}, \mathrm{Mo}, \mathrm{W}, \mathrm{V}$, and $\mathrm{Mn}$ are the key elements that constitute the metal cofactors in metalloenzymes (Klotz and Stein, 2008; Nitschke et al., 2013; Simon and Klotz, 2013; Gómez-Consarnau and SañudoWilhelmy, 2015). The valence, speciation, solubility, adsorption, organic complexation and rates of redox processes of transition metals are subject to influences by physicochemical conditions such as environmental $\mathrm{pH}, \mathrm{O}_{2}$ content and redox potentials (Byrne et al., 1988; Banks et al., 2012; Sunda, 2012; Scholz et al., 2014). The properties of transition metals in marine environments are influenced by diverse biological factors as well (Morel and Price, 2003; Gerringa et al., 2016). The recently proposed "Ferrojan Horse Hypothesis" highlights a newly discovered viral mechanism for the behaviors of $\mathrm{Fe}$ in marine environments (Bonnain et al., 2016). Under global change impacts such as those from ocean warming, acidification, and deoxygenation, the bioavailability and bioactivity of some of these transition metals may be altered (Hoffmann et al., 2012; Gledhill et al., 2015; Emerson, 2016; Stockdale et al., 2016). This may influence the synthesis and activity of certain key metalloenzymes that are involved in microbial energy metabolism, leading to changes of the composition and activity of the marine microbiota and further changes of the marine environment and its functions. For example, AOB employ the Fe-based electron transfer system for ammonia oxidationmediated bioenergetic process, while AOA employ the $\mathrm{Cu}$-based electron transfer system for ammonia oxidation-mediated energy metabolism (Walker et al., 2010; Santoro et al., 2015). Vast areas of marine environments are Fe-limited, particularly in the open oceans. The reliance on $\mathrm{Cu}$ other than $\mathrm{Fe}$ may provide AOA an eco-energetic advantage over $\mathrm{AOB}$ and contribute to the dominance of AOA in many marine environments (Walker et al., 2010). However, seawater $\mathrm{Cu}$ and Fe concentrations and speciation are subject to variation. The scarcity of bioavailable $\mathrm{Cu}$ in certain marine environments may impose a limitation on AOA abundance and activity (Jacquot et al., 2014; Shiozaki et al., 2016). There exist steep concentration gradients of $\mathrm{Cu}$ and $\mathrm{Fe}$ in marine OMZs, where suboxic and anoxic conditions decrease dissolved $\mathrm{Cu}$ concentrations but increase dissolved $\mathrm{Fe}$ concentrations and these trace metal profiles concur with the in situ $\mathrm{Cu}$ metalloenzyme gene profile of ammonia-oxidizing 
Thaumarchaeota and the Fe metalloenzyme gene profile of anammox Planctomycetes, respectively (Glass et al., 2015). The temporospatial distribution and dynamics of transition metals may be an important factor determining the temporospatial distribution and dynamics of the various microbial energetic pathways and functions in the ocean. Researches on this aspect are rare and certainly need to be strengthened.

Most of the microbial metalloenzymes are sensitive to the inhibitory effects of heavy metals. Genes encoding heavy metal resistance are much more abundant in the genome of $\mathrm{Ca}$. Nitrososphaera gargensis isolated from a heavy metal-containing hot spring than in AOA isolated from marine environments (Spang et al., 2012). This indicates that AOA need specific genetic and biochemical mechanisms for heavy metal resistance and marine AOA may be sensitive to the inhibitory effects of heavy metals. Ongoing marine environmental changes caused by ocean warming, acidification, deoxygenation, eutrophication, and pollution may change the concentration, speciation, solubility and mobility of heavy metals as well, particularly in estuarine and coastal environments where heavy metal contaminations are usually prevalent (Atkinson et al., 2007; Millero et al., 2009; Gao et al., 2014; Zeng et al., 2015). The global change problem may be worsened by the compounding effects of heavy metals on the marine microbial processes and functions. The complex interactions between the energy metabolic processes and element biogeochemical cycles indicate that the eco-energetics of the marine microbiota need to be studied with a multidisciplinary effort (Klotz, 2010).

\section{FUTURE PERSPECTIVES ON MARINE CHEMOLITHOAUTOTROPHIC ECO-ENERGETIC RESEARCH}

Microbial metabolism is driven by thermodynamic favorability, which is determined by the availability of free energy in the involved biochemical reactions. Energy is therefore an important constraint, along with nutrients, on the physiology of any organism and the structure and function of any ecosystem. For example, low light availability exerts an energy limitation on the photosynthetic productivity though nutrients are abundant in eutrophic estuaries with high seawater turbidity (Dang and Jiao, 2014). On the contrary, the lack of reduced inorganic chemicals such as $\mathrm{NH}_{4}{ }^{+} / \mathrm{NH}_{3}$ and $\mathrm{H}_{2} \mathrm{~S}$ as energy substrates exerts a limitation on the chemolithoautotrophic primary production in the oxic deep oceans where nutrients such as nitrate and phosphate are usually available.

Environmental physicochemical conditions may exert important constraints on Gibbs energy yields and activity rates of the marine microbiota. For example, it has recently been found that the temperature-pH-salinity extremes exert a much stronger effect on the growth of anaerobically respiring and fermentative bacterial and archaeal strains than on the growth of aerobically respiring strains (Harrison et al., 2015). The difference in living parameter spaces between anaerobic microorganisms and aerobic microorganisms is likely related to their distinct eco-energetic properties. ATP yields of aerobically respiring microorganisms can be an order of magnitude higher than those of the anaerobically respiring or fermentative microorganisms, enabling better performances of aerobes in stress resistance, growth and activity over a broader range of physicochemical extremes (Harrison et al., 2015). This rule may be applicable to the chemolithoautotrophic microorganisms as well. The eco-energetic differences between the aerobic and anaerobic chemolithoautotrophic microorganisms may also affect their respective performances and functions under physicochemical extremes. Although it has not yet been systematically investigated, this hypothesis is important for understanding some of the mechanisms that lead to the compositional and functional shift of the marine microbiota under the various global change impacts.

Ecosystem energy flow involves diverse metabolic pathways (usually harbored by different microorganisms) and their interactions at various temporal and spatial scales. A community perspective is needed for the understanding and study of ocean biogeochemistry and eco-energetics (Figure 1) (Strom, 2008). Many ecophysiological activities and biogeochemical functions of the marine microbiota are carried out through microbial interactions including both cooperation and competition (Litchman et al., 2015; Dang and Lovell, 2016). For example, marine AOA usually have very small cell sizes and genomes (Martens-Habbena et al., 2009; Bayer et al., 2016), providing certain eco-energetic advantages particularly in oligotrophic environments (Batut et al., 2014; Martínez-Cano et al., 2015). Due to genome reduction, some marine AOA have lost the genes that encode for the catalase-peroxidase proteins (Kim et al., 2016). This energetic economy necessitates the dependency of these AOA on other co-occurring microorganisms for oxidative damage protection. The dependence of genome-reduced microorganisms on other microorganisms facilitates the development of metabolic collaborations and other mutualistic interactions in microbial communities. In addition to producing phosphonates for sharing with other microorganisms as a phosphorus source (Metcalf et al., 2012), marine AOA also harbor the genes for synthesis of vitamin $B_{12}$ (Doxey et al., 2015), an essential cofactor required by many marine organisms (Gómez-Consarnau and Sañudo-Wilhelmy, 2015). Auxotrophy and physiological complementation, among many other microbial interactions, may help establish metabolic interconnectedness in natural microbial communities (Giovannoni et al., 2014; Garcia et al., 2015; Kouzuma et al., 2015). Microbial interactions are one of the key intrinsic properties of natural microbial communities that defines not only the composition and structure but also the activity and function of the communities (Hunt and Ward, 2015). Therefore, a systems ecology approach is needed for eco-energetic analyses of the marine ecosystems, in particular for a mechanistic understanding of the ecosystems' driving force, the energy flow along the electron transfer pathways and redox exchange-induced matter fluxes within the marine microbiomes (Kolber, 2007).

In the past, investigations based on matter metabolism and fluxes became the mainstream of marine ecology research, though energy metabolism plays an equally important role on 
the structure and function of marine ecosystems. A few attempts have been made on eco-energetic analyses for certain marine environments (e.g., Amend et al., 2003; Akerman et al., 2011; Dahle et al., 2015; LaRowe and Amend, 2015; Bach, 2016). Most of these analyses focused on energylimited environments such as the subseafloor deep biosphere where only the maintenance energy of the studied microbial community needs to be considered. However, community growth-related temporospatial variation is common in many marine environments, which need more sophisticated and dynamic eco-energetic processes to be taken into consideration for the analyses (Vallino and Algar, 2016). With the advance of the "omics" approaches such as metagenomics, metatranscriptomics, and metaproteomics for community metabolic network analyses, a comprehensive understanding of the mechanisms, processes and environmental responses may be obtained about the functions of marine microbial communities (Morris et al., 2010; Bodrossy, 2015; Reed et al., 2015; Perez-Garcia et al., 2016). These may also help to understand the genetic, biochemical and physiological constraints on the coupling or uncoupling of metabolic processes among different microorganisms or functional groups in an environment. Just like people need two legs to walk, the combination of the "omics" techniques with in situ energy and matter flux measurements or calculations may help to develop advanced biogeochemical models for better understanding and prediction of the processes and functions

\section{REFERENCES}

Akerman, N. H., Price, R. E., Pichler, T., and Amend, J. P. (2011). Energy sources for chemolithotrophs in an arsenic- and iron-rich shallow-sea hydrothermal system. Geobiology 9, 436-445. doi: 10.1111/j.1472-4669.2011.00291.x

Alonso-Sáez, L., Waller, A. S., Mende, D. R., Bakker, K., Farnelid, H., Yager, P. L., et al. (2012). Role for urea in nitrification by polar marine Archaea. Proc. Natl. Acad. Sci. U.S.A. 109, 17989-17994. doi: 10.1073/pnas.1201914109

Amend, J. P., Rogers, K. L., Shock, E. L., Gurrieri, S., and Inguaggiato, S. (2003). Energetics of chemolithoautotrophy in the hydrothermal system of Vulcano Island, southern Italy. Geobiology 1, 37-58. doi: 10.1046/j.1472-4669.2003. 00006.x

Andersson, A. J., and Gledhill, D. (2013). Ocean acidification and coral reefs: effects on breakdown, dissolution, and net ecosystem calcification. Annu. Rev. Mar. Sci. 5, 321-348. doi: 10.1146/annurev-marine-121211-172241

Anderson, I., Risso, C., Holmes, D., Lucas, S., Copeland, A., Lapidus, A., et al. (2011). Complete genome sequence of Ferroglobus placidus AEDII12DO. Stand. Genomic Sci. 5, 50-60. doi: 10.4056/sigs.2225018

Arp, D. J., Chain, P. S., and Klotz, M. G. (2007). The impact of genome analyses on our understanding of ammonia-oxidizing bacteria. Annu. Rev. Microbiol. 61, 503-528. doi: 10.1146/annurev.micro.61.080706.093449

Arrieta, J. M., Mayol, E., Hansman, R. L., Herndl, G. J., Dittmar, T., and Duarte, C. M. (2015). Dilution limits dissolved organic carbon utilization in the deep ocean. Science 348, 331-333. doi: 10.1126/science.1258955

Arrigo, K. R. (2005). Marine microorganisms and global nutrient cycles. Nature 437, 349-355. doi: 10.1038/nature04159

Atkinson, C. A., Jolley, D. F., and Simpson, S. L. (2007). Effect of overlying water $\mathrm{pH}$, dissolved oxygen, salinity and sediment disturbances on metal release and sequestration from metal contaminated marine sediments. Chemosphere 69, 428-437. doi: 10.1016/j.chemosphere.2007.04.068

Azam, F. (1998). Microbial control of oceanic carbon flux: the plot thickens. Science 280, 694-696. doi: 10.1126/science.280.5364.694

Azam, F., Fenchel, T., Field, J. G., Gray, J. S., Meyer-Reil, L. A., and Thingstad, F. (1983). The ecological role of water-column microbes in the sea. Mar. Ecol. Prog. Ser. 10, 257-263. doi: 10.3354/meps010257 of the marine ecosystems and their responses to the global change impacts (Kolber, 2007; Soh and Hatzimanikatis, 2010; Vallino and Algar, 2016).

\section{AUTHOR CONTRIBUTIONS}

All authors listed have made a substantial, direct and intellectual contribution to the work, and approved it for publication.

\section{FUNDING}

This work was supported by the China SOA grant GASI-0301-02-05, National Key Research and Development Program of China grant 2016YFA0601303, China MOST 973 program grant 2013CB955700, NSFC grants 91328209, 41676122, and 91428308, and CNOOC grants CNOOC-KJ 125 FZDXM 00TJ 001-2014 and CNOOC-KJ 125 FZDXM 00ZJ 001-2014.

\section{ACKNOWLEDGMENT}

We thank professor Martin G. Klotz (City University of New York) for valuable discussions and manuscript improvement and the two reviewers for their valuable comments.

Azam, F., and Malfatti, F. (2007). Microbial structuring of marine ecosystems. Nat. Rev. Microbiol. 5, 782-791. doi: 10.1038/nrmicro1747

Babbin, A. R., Bianchi, D., Jayakumar, A., and Ward, B. B. (2015). Rapid nitrous oxide cycling in the suboxic ocean. Science 348, 1127-1129. doi: 10.1126/ science.aaa8380

Babbin, A. R., Jayakumar, A., and Ward, B. B. (2016). Organic matter loading modifies the microbial community responsible for nitrogen loss in estuarine sediments. Microb. Ecol. 71, 555-565. doi: 10.1007/s00248-015-0693-5

Babbin, A. R., Keil, R. G., Devol, A. H., and Ward, B. B. (2014). Organic matter stoichiometry, flux, and oxygen control nitrogen loss in the ocean. Science 344, 406-408. doi: 10.1126/science. 1248364

Bach, W. (2016). Some compositional and kinetic controls on the bioenergetic landscapes in oceanic basement. Front. Microbiol. 7:107. doi: 10.3389/fmicb. 2016.00107

Baer, S. E., Connelly, T. L., Sipler, R. E., Yager, P. L., and Bronk, D. A. (2014). Effect of temperature on rates of ammonium uptake and nitrification in the western coastal Arctic during winter, spring, and summer. Global Biogeochem. Cycles 28, 1455-1466. doi: 10.1002/2013GB004765

Banks, J. L., Ross, D. J., Keough, M. J., Eyre, B. D., and Macleod, C. K. (2012). Measuring hypoxia induced metal release from highly contaminated estuarine sediments during a 40 day laboratory incubation experiment. Sci. Total Environ. 420, 229-237. doi: 10.1016/j.scitotenv.2012.01.033

Barco, R. A., Emerson, D., Sylvan, J. B., Orcutt, B. N., Jacobson Meyers, M. E., Ramírez, G. A., et al. (2015). New insight into microbial iron oxidation as revealed by the proteomic profile of an obligate iron-oxidizing chemolithoautotroph. Appl. Environ. Microbiol. 81, 5927-5937. doi: 10.1128/ AEM.01374-15

Bar-Even, A., Flamholz, A., Noor, E., and Milo, R. (2012). Thermodynamic constraints shape the structure of carbon fixation pathways. Biochim. Biophys. Acta 1817, 1646-1659. doi: 10.1016/j.bbabio.2012.05.002

Batut, B., Knibbe, C., Marais, G., and Daubin, V. (2014). Reductive genome evolution at both ends of the bacterial population size spectrum. Nat. Rev. Microbiol. 12, 841-850. doi: 10.1038/nrmicro3331

Bayer, B., Vojvoda, J., Offre, P., Alves, R. J., Elisabeth, N. H., Garcia, J. A., et al. (2016). Physiological and genomic characterization of two novel marine 
thaumarchaeal strains indicates niche differentiation. ISME J. 10, 1051-1063. doi: 10.1038/ismej.2015.200

Beman, J. M., Chow, C. E., King, A. L., Feng, Y., Fuhrman, J. A., Andersson, A., et al. (2011). Global declines in oceanic nitrification rates as a consequence of ocean acidification. Proc. Natl. Acad. Sci. U.S.A. 108, 208-213. doi: 10.1073/ pnas. 1011053108

Beman, J. M., Shih, J. L., and Popp, B. N. (2013). Nitrite oxidation in the upper water column and oxygen minimum zone of the eastern tropical North Pacific Ocean. ISME J. 7, 2192-2205. doi: 10.1038/ismej.2013.96

Beman, J. M., Popp, B. N., and Alford, S. E. (2012). Quantification of ammonia oxidation rates and ammonia-oxidizing archaea and bacteria at high resolution in the Gulf of California and eastern tropical North Pacific Ocean. Limnol. Oceanogr. 57, 711-726. doi: 10.4319/lo.2012.57.3.0711

Benitez-Nelson, C. (2015). The missing link in oceanic phosphorus cycling? Science 348, 759-760. doi: 10.1126/science.aab2801

Berg, C., Listmann, L., Vandieken, V., Vogts, A., and Jürgens, K. (2015a). Chemoautotrophic growth of ammonia-oxidizing Thaumarchaeota enriched from a pelagic redox gradient in the Baltic Sea. Front. Microbiol. 5:786. doi: $10.3389 /$ fmicb. 2014.00786

Berg, C., Vandieken, V., Thamdrup, B., and Jürgens, K. (2015b). Significance of archaeal nitrification in hypoxic waters of the Baltic Sea. ISME J. 9, 1319-1332. doi: 10.1038/ismej.2014.218

Berg, I. A. (2011). Ecological aspects of the distribution of different autotrophic $\mathrm{CO}_{2}$ fixation pathways. Appl. Environ. Microbiol. 77, 1925-1936. doi: 10.1128/ AEM.02473-10

Berg, I. A., Kockelkorn, D., Buckel, W., and Fuchs, G. (2007). A 3hydroxypropionate/4-hydroxybutyrate autotrophic carbon dioxide assimilation pathway in Archaea. Science 318, 1782-1786. doi: 10.1126/ science. 1149976

Berg, I. A., Kockelkorn, D., Ramos-Vera, W. H., Say, R. F., Zarzycki, J., Hügler, M., et al. (2010). Autotrophic carbon fixation in archaea. Nat. Rev. Microbiol. 8, 447-460. doi: 10.1038/nrmicro2365

Berman, T., and Bronk, D. A. (2003). Dissolved organic nitrogen: a dynamic participant in aquatic ecosystems. Aquat. Microb. Ecol. 31, 279-305. doi: $10.3354 /$ ame 031279

Berry, S. (2002). The chemical basis of membrane bioenergetics. J. Mol. Evol. 54, 595-613. doi: 10.1007/s00239-001-0056-3

Bijma, J., Pörtner, H. O., Yesson, C., and Rogers, A. D. (2013). Climate change and the oceans - What does the future hold? Mar. Pollut. Bull. 74, 495-505. doi: 10.1016/j.marpolbul.2013.07.022

Bodrossy, L. (2015). The full metagenomics cycle. Environ. Microbiol. 17, 4819-4821. doi: 10.1111/1462-2920.13040

Boetius, A., Ravenschlag, K., Schubert, C. J., Rickert, D., Widdel, F., Gieseke, A., et al. (2000). A marine microbial consortium apparently mediating anaerobic oxidation of methane. Nature 407, 623-626. doi: 10.1038/35 036572

Bombar, D., Paerl, R. W., and Riemann, L. (2016). Marine non-cyanobacterial diazotrophs: moving beyond molecular detection. Trends Microbiol. 24, 916-927. doi: 10.1016/j.tim.2016.07.002

Bonnain, C., Breitbart, M., and Buck, K. N. (2016). The ferrojan horse hypothesis: iron-virus interactions in the ocean. Front. Mar. Sci. 3:82. doi: 10.3389/fmars. 2016.00082

Bowen, J. L., Kearns, P. J., Holcomb, M., and Ward, B. B. (2013). Acidification alters the composition of ammonia-oxidizing microbial assemblages in marine mesocosms. Mar. Ecol. Prog. Ser. 492, 1-8. doi: 10.3354/meps10526

Bowler, C., Vardi, A., and Allen, A. E. (2010). Oceanographic and biogeochemical insights from diatom genomes. Annu. Rev. Mar. Sci. 2, 333-365. doi: 10.1146/ annurev-marine-120308-081051

Braakman, R., and Smith, E. (2012). The emergence and early evolution of biological carbon-fixation. PLoS Comput. Biol. 8:e1002455. doi: 10.1371/ journal.pcbi. 1002455

Brady, A. L., Sharp, C. E., Grasby, S. E., and Dunfield, P. F. (2015). Anaerobic carboxydotrophic bacteria in geothermal springs identified using stable isotope probing. Front. Microbiol. 6:897. doi: 10.3389/fmicb.2015. 00897

Braeckman, U., Van Colen, C., Guilini, K., Van Gansbeke, D., Soetaert, K., Vincx, M., et al. (2014). Empirical evidence reveals seasonally dependent reduction in nitrification in coastal sediments subjected to near future ocean acidification. PLOS ONE 9:e108153. doi: 10.1371/journal.pone. 0108153

Branch, T. A., DeJoseph, B. M., Ray, L. J., and Wagner, C. A. (2013). Impacts of ocean acidification on marine seafood. Trends Ecol. Evol. 28, 178-186. doi: 10.1016/j.tree.2012.10.001

Brin, L. D., Giblin, A. E., and Rich, J. J. (2017). Similar temperature responses suggest future climate warming will not alter partitioning between denitrification and anammox in temperate marine sediments. Glob. Chang. Biol. 23, 331-340. doi: 10.1111/gcb.13370

Bristow, L. A., Dalsgaard, T., Tiano, L., Mills, D. B., Bertagnolli, A. D., Wright, J. J., et al. (2016). Ammonium and nitrite oxidation at nanomolar oxygen concentrations in oxygen minimum zone waters. Proc. Natl. Acad. Sci. U.S.A. 113, 10601-10606. doi: 10.1073/pnas.1600359113

Bristow, L. A., Sarode, N., Cartee, J., Caro-Quintero, A., Thamdrup, B., and Stewart, F. J. (2015). Biogeochemical and metagenomic analysis of nitrite accumulation in the Gulf of Mexico hypoxic zone. Limnol. Oceanogr. 60, 1733-1750. doi: 10.1002/lno.10130

Brochier-Armanet, C., Boussau, B., Gribaldo, S., and Forterre, P. (2008). Mesophilic crenarchaeota: proposal for a third archaeal phylum, the Thaumarchaeota. Nat. Rev. Microbiol. 6, 245-252. doi: 10.1038/nrmicro 1852

Brondizio, E. S., O’Brien, K., Bai, X., Biermann, F., Steffen, W., Berkhout, F., et al. (2016). Re-conceptualizing the anthropocene: a call for collaboration. Glob. Environ. Change 39, 318-327. doi: 10.1016/j.gloenvcha.2016. 02.006

Brown, M. V., Ostrowski, M., Grzymski, J. J., and Lauro, F. M. (2014). A trait based perspective on the biogeography of common and abundant marine bacterioplankton clades. Mar. Genomics 15, 17-28. doi: 10.1016/j.margen.2014. 03.002

Buchwald, C., and Casciotti, K. L. (2013). Isotopic ratios of nitrite as tracers of the sources and age of oceanic nitrite. Nat. Geosci. 6, 308-313. doi: 10.1038/ ngeo 1745

Burgin, A. J., Yang, W. H., Hamilton, S. K., and Silver, W. L. (2011). Beyond carbon and nitrogen: how the microbial energy economy couples elemental cycles in diverse ecosystems. Front. Ecol. Environ. 9, 44-52. doi: 10.1890/ 090227

Byrne, R. H., Kump, L. R., and Cantrell, K. J. (1988). The influence of temperature and $\mathrm{pH}$ on trace metal speciation in seawater. Mar. Chem. 25, 163-181. doi: 10.1016/0304-4203(88)90062-X

Cai, W. J., Hu, X. P., Huang, W. J., Murrell, M. C., Lehrter, J. C., Lohrenz, S. E., et al. (2011). Acidification of subsurface coastal waters enhanced by eutrophication. Nat. Geosci. 4, 766-770. doi: 10.1038/ngeo1297

Caldeira, K., and Wickett, M. E. (2005). Ocean model predictions of chemistry changes from carbon dioxide emissions to the atmosphere and ocean. J. Geophys. Res. 110, C09S04. doi: 10.1029/2004JC 002671

Campbell, B. J., Smith, J. L., Hanson, T. E., Klotz, M. G., Stein, L. Y., Lee, C. K., et al. (2009). Adaptations to submarine hydrothermal environments exemplified by the genome of Nautilia profundicola. PLoS Genet. 5:e1000362. doi: 10.1371/ journal.pgen.1000362

Campbell, M. A., Chain, P. S., Dang, H., El Sheikh, A. F., Norton, J. M., Ward, N. L., et al. (2011). Nitrosococcus watsonii sp. nov., a new species of marine obligate ammonia-oxidizing bacteria that is not omnipresent in the world's oceans: calls to validate the names 'Nitrosococcus halophilus' and 'Nitrosomonas mobilis'. FEMS Microbiol. Ecol. 76, 39-48. doi: 10.1111/j.1574-6941.2010. 01027.x

Canfield, D. E., Glazer, A. N., and Falkowski, P. G. (2010a). The evolution and future of Earth's nitrogen cycle. Science 330, 192-196. doi: 10.1126/science. 1186120

Canfield, D. E., Stewart, F. J., Thamdrup, B., De Brabandere, L., Dalsgaard, T., DeLong, E. F., et al. (2010b). A cryptic sulfur cycle in oxygen-minimum-zone waters off the Chilean coast. Science 330, 1375-1378. doi: 10.1126/science. 1196889

Canion, A., Kostka, J. E., Gihring, T. M., Huettel, M., van Beusekom, J. E. E., Gao, H., et al. (2014a). Temperature response of denitrification and anammox reveals the adaptation of microbial communities to in situ temperatures in permeable marine sediments that span $50^{\circ}$ in latitude. Biogeosciences 11, 309-320. doi: 10.5194/bg-11-309-2014 
Canion, A., Overholt, W. A., Kostka, J. E., Huettel, M., Lavik, G., and Kuypers, M. M. (2014b). Temperature response of denitrification and anaerobic ammonium oxidation rates and microbial community structure in Arctic fjord sediments. Environ. Microbiol. 16, 3331-3344. doi: 10.1111/1462-2920. 12593

Capone, D. G., and Hutchins, D. A. (2013). Microbial biogeochemistry of coastal upwelling regimes in a changing ocean. Nat. Geosci. 6, 711-717. doi: 10.1038/ ngeo1916

Carolan, M. T., Smith, J. M., and Beman, J. M. (2015). Transcriptomic evidence for microbial sulfur cycling in the eastern tropical North Pacific oxygen minimum zone. Front. Microbiol. 6:334. doi: 10.3389/fmicb.2015.00334

Carpenter, L. J., Archer, S. D., and Beale, R. (2012). Ocean-atmosphere trace gas exchange. Chem. Soc. Rev. 41, 6473-6506. doi: 10.1039/c2cs $35121 \mathrm{~h}$

Castro-González, M., and Farías, L. (2015). The influence of anoxia and substrate availability on $\mathrm{N}_{2} \mathrm{O}$ cycling by denitrification in the upper boundary of the oxygen minimum zone off northern Chile. J. Mar. Res. 73, 185-205. doi: $10.1357 / 002224015817391285$

Chang, B. X., Rich, J. R., Jayakumar, A., Naik, H., Pratihary, A. K., Keil, R. G., et al. (2014). The effect of organic carbon on fixed nitrogen loss in the eastern tropical South Pacific and Arabian Sea oxygen deficient zones. Limnol. Oceanogr. 59, 1267-1274. doi: 10.4319/lo.2014.59.4.1267

Chen, C. T. A. (2011). Microbial carbon pump: additional considerations. Nat. Rev. Microbiol. 9, 555. doi: 10.1038/nrmicro2386-c4

Codispoti, L. A. (2007). An oceanic fixed nitrogen sink exceeding $400 \mathrm{Tg} \mathrm{N}$ a-1 vs the concept of homeostasis in the fixed-nitrogen inventory. Biogeosciences 4, 233-253. doi: 10.5194/bg-4-233-2007

Codispoti, L. A. (2010). Interesting times for marine $\mathrm{N}_{2}$ O. Science 327, 1339-1340. doi: 10.1126/science. 1184945

Codispoti, L. A., Brandes, J. A., Christensen, J. P., Devol, A. H., Naqvi, S. W. A., Paerl, H. W., et al. (2001). The oceanic fixed nitrogen and nitrous oxide budgets: moving targets as we enter the anthropocene? Sci. Mar. 65, 85-105. doi: $10.3989 /$ scimar.2001.65s 285

Connelly, T. L., Baer, S. E., Cooper, J. T., Bronk, D. A., and Wawrik, B. (2014). Urea uptake and carbon fixation by marine pelagic bacteria and archaea during the Arctic summer and winter seasons. Appl. Environ. Microbiol. 80, 6013-6022. doi: 10.1128/AEM.01431-14

Corinaldesi, C. (2015). New perspectives in benthic deep-sea microbial ecology. Front. Mar. Sci. 2:17. doi: 10.3389/fmars.2015.00017

Costa, E., Pérez, J., and Kreft, J. U. (2006). Why is metabolic labour divided in nitrification? Trends Microbiol. 14, 213-219. doi: 10.1016/j.tim.2006. 03.006

Cripps, G., Flynn, K. J., and Lindeque, P. K. (2016). Ocean acidification affects the phyto-zoo plankton trophic transfer efficiency. PLoS ONE 11:e0151739. doi: 10.1371 /journal.pone.0151739

Dahle, H., Økland, I., Thorseth, I. H., Pederesen, R. B., and Steen, I. H. (2015). Energy landscapes shape microbial communities in hydrothermal systems on the Arctic Mid-Ocean Ridge. ISME J. 9, 1593-1606. doi: 10.1038/ismej. 2014.247

Daims, H., Lebedeva, E. V., Pjevac, P., Han, P., Herbold, C., Albertsen, M., et al. (2015). Complete nitrification by Nitrospira bacteria. Nature 528, 504-509. doi: 10.1038/nature16461

Daims, H., Lücker, S., and Wagner, M. (2016). A new perspective on microbes formerly known as nitrite-oxidizing bacteria. Trends Microbiol. 24, 699-712. doi: 10.1016/j.tim.2016.05.004

Dalsgaard, T., Canfield, D., Petersen, J., Thamdrup, B., and Acuña-González, J. (2003). N2 production by the anammox reaction in the anoxic water column of Golfo Dulce. Costa Rica. Nature 422, 606-608. doi: 10.1038/nature 01526

Dalsgaard, T., Stewart, F. J., Thamdrup, B., De Brabandere, L., Revsbech, N. P., Ulloa, O., et al. (2014). Oxygen at nanomolar levels reversibly suppresses process rates and gene expression in anammox and denitrification in the oxygen minimum zone off northern Chile. mBio 5:e01966-14. doi: 10.1128/ mBio.01966- 14

Damashek, J., Casciotti, K. L., and Francis, C. A. (2016). Variable nitrification rates across environmental gradients in turbid, nutrient-rich estuary waters of San Francisco Bay. Estuar. Coasts 39, 1050-1071. doi: 10.1007/s12237-0160071-7
Dang, H., and Jiao, N. (2014). Perspectives on the microbial carbon pump with special reference to microbial respiration and ecosystem efficiency in large estuarine systems. Biogeosciences 11, 3887-3898. doi: 10.5194/bg-11-3887-2014

Dang, H. Y., Chen, R. P., Wang, L., Guo, L. Z., Chen, P. P., Tang, Z. W., et al. (2010a). Environmental factors shape sediment anammox bacterial communities in hypernutrified Jiaozhou Bay, China. Appl. Environ. Microbiol. 76, 7036-7047. doi: 10.1128/AEM.01264-10

Dang, H. Y., Chen, R. P., Wang, L., Shao, S. D., Dai, L. Q., Ye, Y., et al. (2011). Molecular characterization of putative biocorroding microbiota with a novel niche detection of Epsilon- and Zetaproteobacteria in Pacific Ocean coastal seawaters. Environ. Microbiol. 13, 3059-3074. doi: 10.1111/j.1462-2920.2011. 02583.X

Dang, H. Y., Li, J., Chen, R. P., Wang, L., Guo, L. Z., Zhang, Z. N., et al. (2010b). Diversity, abundance, and spatial distribution of sediment ammoniaoxidizing Betaproteobacteria in response to environmental gradients and coastal eutrophication in Jiaozhou Bay, China. Appl. Environ. Microbiol. 76, 4691-4702. doi: 10.1128/AEM.02563-09

Dang, H. Y., Li, T. G., Chen, M. N., and Huang, G. Q. (2008a). Crossocean distribution of Rhodobacterales bacteria as primary surface colonizers in temperate coastal marine waters. Appl. Environ. Microbiol. 74, 52-60. doi: 10.1128/AEM.01400-07

Dang, H. Y., and Lovell, C. R. (2016). Microbial surface colonization and biofilm development in marine environments. Microbiol. Mol. Biol. Rev. 80, 91-138. doi: 10.1128/MMBR.00037-15

Dang, H. Y., Luan, X. W., Chen, R. P., Zhang, X. X., Guo, L. Z., and Klotz, M. G. (2010c). Diversity, abundance and distribution of amoA-encoding archaea in deep-sea methane seep sediments of the Okhotsk Sea. FEMS Microbiol. Ecol. 72, 370-385. doi: 10.1111/j.1574-6941.2010.00870.x

Dang, H. Y., Luan, X. W., Zhao, J. Y., and Li, J. (2009a). Diverse and novel nif $H$ and nifH-like gene sequences in the deep-sea methane seep sediments of the Okhotsk Sea. Appl. Environ. Microbiol. 75, 2238-2245. doi: 10.1128/AEM. 02556-08

Dang, H. Y., Wang, C. Y., Li, J., Li, T. G., Tian, F., Jin, W., et al. (2009b). Diversity and distribution of sediment nirS-encoding bacterial assemblages in response to environmental gradients in the eutrophied Jiaozhou Bay, China. Microb. Ecol. 58, 161-169. doi: 10.1007/s00248-008-9469-5

Dang, H. Y., Yang, J. Y., Li, J., Luan, X. W., Zhang, Y. B., Gu, G. Z., et al. (2013a). Environment-dependent distribution of the sediment nifH-harboring microbiota in the northern South China Sea. Appl. Environ. Microbiol. 79, 121-132. doi: 10.1128/AEM.01889-12

Dang, H. Y., Zhang, X. X., Sun, J., Li, T. G., Zhang, Z. N., and Yang, G. P. (2008b). Diversity and spatial distribution of sediment ammonia-oxidizing crenarchaeota in response to estuarine and environmental gradients in the Changjiang Estuary and East China Sea. Microbiology 154, 2084-2095. doi: 10.1099/mic.0.2007/013581-0

Dang, H. Y., Zhou, H. X., Yang, J. Y., Ge, H. M., Jiao, N. Z., Luan, X. W., et al. (2013b). Thaumarchaeotal signature gene distribution in sediments of the northern South China Sea: an indicator of the metabolic intersection of the marine carbon, nitrogen, and phosphorus cycles? Appl. Environ. Microbiol. 79, 2137-2147. doi: 10.1128/AEM.03204-12

Dang, H. Y., Zhou, H. X., Zhang, Z. N., Yu, Z. S., Hua, E., Liu, X. S., et al. (2013c). Molecular detection of Candidatus Scalindua pacifica and environmental responses of sediment anammox bacterial community in the Bohai Sea, China. PLoS ONE 8:e61330. doi: 10.1371/journal.pone.0061330

Dekas, A. E., Poretsky, R. S., and Orphan, V. J. (2009). Deep-sea archaea fix and share nitrogen in methane-consuming microbial consortia. Science 326, 422-426. doi: 10.1126/science. 1178223

DeLong, E. F. (2009). The microbial ocean from genomes to biomes. Nature 459, 200-206. doi: 10.1038/nature08059

Devol, A. H. (2015). Denitrification, anammox, and $\mathrm{N}_{2}$ production in marine sediments. Ann. Rev. Mar. Sci. 7, 403-423. doi: 10.1146/annurev-marine010213-135040

Diner, R. E., Schwenck, S. M., McCrow, J. P., Zheng, H., and Allen, A. E. (2016). Genetic manipulation of competition for nitrate between heterotrophic bacteria and diatoms. Front. Microbiol. 7:880. doi: 10.3389/fmicb.2016. 00880

Dodsworth, J. A., McDonald, A. I., and Hedlund, B. P. (2012). Calculation of total free energy yield as an alternative approach for predicting the importance of 
potential chemolithotrophic reactions in geothermal springs. FEMS Microbiol. Ecol. 81, 446-454. doi: 10.1111/j.1574-6941.2012.01369.x

Doney, S. C. (2010). The growing human footprint on coastal and openocean biogeochemistry. Science 328, 1512-1516. doi: 10.1126/science. 1185198

Doney, S. C., Fabry, V. J., Feely, R. A., and Kleypas, J. A. (2009). Ocean acidification: the other $\mathrm{CO}_{2}$ problem. Annu. Rev. Mar. Sci. 1, 169-192. doi: 10.1146/annurev. marine.010908.163834

Doney, S. C., Mahowald, N., Lima, I., Feely, R. A., Mackenzie, F. T., Lamarque, J. F., et al. (2007). Impact of anthropogenic atmospheric nitrogen and sulfur deposition on ocean acidification and the inorganic carbon system. Proc. Natl. Acad. Sci. U.S.A. 104, 14580-14585. doi: 10.1073/pnas.0702218104

Doxey, A. C., Kurtz, D. A., Lynch, M. D., Sauder, L. A., and Neufeld, J. D. (2015). Aquatic metagenomes implicate Thaumarchaeota in global cobalamin production. ISME J. 9, 461-471. doi: 10.1038/ismej.2014.142

Duarte, C. M. (2014). Global change and the future ocean: a grand challenge for marine sciences. Front. Mar. Sci. 1:63. doi: 10.3389/fmars.2014.00063

Dworkin, M. (2012). Sergei Winogradsky: a founder of modern microbiology and the first microbial ecologist. FEMS Microbiol. Rev. 36, 364-379. doi: 10.1111/j. 1574-6976.2011.00299.x

Eggleston, E. M., Lee, D. Y., Owens, M. S., Cornwell, J. C., Crump, B. C., and Hewson, I. (2015). Key respiratory genes elucidate bacterial community respiration in a seasonally anoxic estuary. Environ. Microbiol. 17, 2306-2318. doi: 10.1111/1462-2920.12690

Eichner, M., Kranz, S. A., and Rost, B. (2014). Combined effects of different $\mathrm{CO} 2$ levels and $\mathrm{N}$ sources on the diazotrophic cyanobacterium Trichodesmium. Physiol. Plant. 152, 316-330. doi: 10.1111/ppl.12172

Emerson, D. (2016). The irony of iron - Biogenic iron oxides as an iron source to the ocean. Front. Microbiol. 6:1502. doi: 10.3389/fmicb.2015.01502

Emerson, D., and Moyer, C. L. (2002). Neutrophilic Fe-oxidizing bacteria are abundant at the Loihi Seamount hydrothermal vents and play a major role in $\mathrm{Fe}$ oxide deposition. Appl. Environ. Microbiol. 68, 3085-3093. doi: 10.1128/AEM. 68.6.3085-3093.2002

Emerson, D., Rentz, J. A., Lilburn, T. G., Davis, R. E., Aldrich, H., Chan, C., et al. (2007). A novel lineage of Proteobacteria involved in formation of marine $\mathrm{Fe}-$ oxidizing microbial mat communities. PLoS ONE 2:e667. doi: 10.1371/journal. pone. 0000667

Engström, P., Dalsgaard, T., Hulth, S., and Aller, R. C. (2005). Anaerobic ammonium oxidation by nitrite (anammox): implications for $\mathrm{N}_{2}$ production in coastal marine sediments. Geochim. Cosmochim. Acta 69, 2057-2065. doi: 10.1016/j.gca.2004.09.032

Falkowski, P. G., Fenchel, T., and DeLong, E. F. (2008). The microbial engines that drive Earth's biogeochemical cycles. Science 320, 1034-1039. doi: 10.1126/ science. 1153213

Falkowski, P. G., and Godfrey, L. V. (2008). Electrons, life and the evolution of Earth's oxygen cycle. Phil. Trans. R. Soc. B 363, 2705-2716. doi: 10.1098/rstb. 2008.0054

Felbeck, H., and Somero, G. N. (1982). Primary production in deep-sea hydrothermal vent organisms: roles of sulfide-oxidizing bacteria. Trends Biochem. Sci. 7, 201-204. doi: 10.1016/0968-0004(82)90088-3

Fernandez, C., Farías, L., and Ulloa, O. (2011). Nitrogen fixation in denitrified marine waters. PLoS ONE 6:e20539. doi: 10.1371/journal.pone.0020539

Follett, C. L., Repeta, D. J., Rothman, D. H., Xu, L., and Santinelli, C. (2014). Hidden cycle of dissolved organic carbon in the deep ocean. Proc. Natl. Acad. Sci. U.S.A. 111, 16706-16711. doi: 10.1073/pnas.1407445111

Frame, C. H., Lau, E., Nolan, E. J. I. V., Goepfert, T. J., and Lehmann, M. F. (2017). Acidification enhances hybrid $\mathrm{N} 2 \mathrm{O}$ production associated with aquatic ammonia-oxidizing microorganisms. Front. Microbiol. 7:2104. doi: 10.3389/ fmicb.2016.02104

Francis, C. A., Roberts, K. J., Beman, J. M., Santoro, A. E., and Oakley, B. B. (2005). Ubiquity and diversity of ammonia-oxidizing archaea in water columns and sediments of the ocean. Proc. Natl. Acad. Sci. U.S.A. 102, 14683-14688. doi: $10.1073 /$ pnas. 0506625102

Fuchs, G. (2011). Alternative pathways of carbon dioxide fixation: insights into the early evolution of life? Annu. Rev. Microbiol. 65, 631-658. doi: 10.1146/ annurev-micro-090110-102801

Fulweiler, R. W. (2009). Fantastic fixers. Science 326, 377-378. doi: 10.1126/science. 1181129
Füssel, J., Lam, P., Lavik, G., Jensen, M. M., Holtappels, M., Günter, M., et al. (2012). Nitrite oxidation in the Namibian oxygen minimum zone. ISME J. 6, 1200-1209. doi: 10.1038/ismej.2011.178

Ganesh, S., Bristow, L. A., Larsen, M., Sarode, N., Thamdrup, B., and Stewart, F. J. (2015). Size-fraction partitioning of community gene transcription and nitrogen metabolism in a marine oxygen minimum zone. ISME J. 9, 2682-2696. doi: 10.1038/ismej.2015.44

Gao, X., Zhou, F., and Chen, C. T. A. (2014). Pollution status of the Bohai Sea: an overview of the environmental quality assessment related trace metals. Environ. Int. 62, 12-30. doi: 10.1016/j.envint.2013.09.019

Garcia, S. L., Buck, M., McMahon, K. D., Grossart, H. P., Eiler, A., and Warnecke, F. (2015). Auxotrophy and intrapopulation complementary in the 'interactome' of a cultivated freshwater model community. Mol. Ecol. 24, 4449-4459. doi: $10.1111 /$ mec.13319

Gazeau, F., van Rijswijk, P., Pozzato, L., and Middelburg, J. J. (2014). Impacts of ocean acidification on sediment processes in shallow waters of the Arctic Ocean. PLoS ONE 9:e94068. doi: 10.1371/journal.pone.0094068

Gerringa, L. J. A., Rijkenberg, M. J. A., Bown, J., Margolin, A. R., Laan, P., and de Baar, H. J. W. (2016). Fe-binding dissolved organic ligands in the oxic and suboxic waters of the Black Sea. Front. Mar. Sci. 3:84. doi: 10.3389/fmars.2016. 00084

Ghosh, W., and Dam, B. (2009). Biochemistry and molecular biology of lithotrophic sulfur oxidation by taxonomically and ecologically diverse bacteria and archaea. FEMS Microbiol. Rev. 33, 999-1043. doi: 10.1111/j.1574-6976. 2009.00187.x

Gilly, W. F., Beman, J. M., Litvin, S. Y., and Robison, B. H. (2013). Oceanographic and biological effects of shoaling of the oxygen minimum zone. Ann. Rev. Mar. Sci. 5, 393-420. doi: 10.1146/annurev-marine-120710-100849

Giovannoni, S. J., Thrash, J. C., and Temperton, B. (2014). Implications of streamlining theory for microbial ecology. ISME J. 8, 1553-1565. doi: 10.1038/ ismej. 2014.60

Glass, J. B., Kretz, C. B., Ganesh, S., Ranjan, P., Seston, S. L., Buck, K. N., et al. (2015). Meta-omic signatures of microbial metal and nitrogen cycling in marine oxygen minimum zones. Front. Microbiol. 6:998. doi: 10.3389/fmicb.2015.00998

Glass, J. B., and Orphan, V. J. (2012). Trace metal requirements for microbial enzymes involved in the production and consumption of methane and nitrous oxide. Front. Microbiol. 3:61. doi: 10.3389/fmicb.2012.00061

Glaubitz, S., Kießlich, K., Meeske, C., Labrenz, M., and Jürgens, K. (2013). SUP05 dominates the gammaproteobacterial sulfur oxidizer assemblages in pelagic redoxclines of the central Baltic and Black Seas. Appl. Environ. Microbiol. 79, 2767-2776. doi: 10.1128/AEM.03777-12

Gledhill, M., Achterberg, E. P., Li, K., Mohamed, K. N., and Rijkenberg, M. J. A. (2015). Influence of ocean acidification on the complexation of iron and copper by organic ligands in estuarine waters. Mar. Chem. 177, 421-433. doi: 10.1016/ j.marchem.2015.03.016

Glibert, P. M., Harrison, J., Heil, C., and Seitzinger, S. (2006). Escalating worldwide use of urea - a global change contributing to coastal eutrophication. Biogeochemistry 77, 441-463. doi: 10.1007/s10533-005-3070-5

Gómez-Consarnau, L., and Sañudo-Wilhelmy, S. A. (2015). Beyond the iron age: the ecological relevance of non-ferrous bioactive trace metals and organic growth factors in aquatic systems. Front. Microbiol. 6:218. doi: 10.3389/fmicb. 2015.00218

Gotschalk, C. C., and Alldredge, A. L. (1989). Enhanced primary production and nutrient regeneration within aggregated marine diatoms. Mar. Biol. 103, 119-129. doi: 10.1007/BF00391070

Graf, D. R., Jones, C. M., and Hallin, S. (2014). Intergenomic comparisons highlight modularity of the denitrification pathway and underpin the importance of community structure for N2O emissions. PLoS ONE 9:e114118. doi: 10.1371/ journal.pone.0114118

Großkopf, T., and Laroche, J. (2012). Direct and indirect costs of dinitrogen fixation in Crocosphaera watsonii WH8501 and possible implications for the nitrogen cycle. Front. Microbiol. 3:236. doi: 10.3389/fmicb.2012. 00236

Großkopf, T., Mohr, W., Baustian, T., Schunck, H., Gill, D., Kuypers, M. M., et al. (2012). Doubling of marine dinitrogen-fixation rates based on direct measurements. Nature 488, 361-364. doi: 10.1038/nature11338

Gruber, N., and Galloway, J. N. (2008). An earth-system perspective of the global nitrogen cycle. Nature 451, 293-296. doi: 10.1038/nature06592 
Hagens, M., Hunter, K. A., Liss, P. S., and Middelburg, J. J. (2014). Biogeochemical context impacts seawater $\mathrm{pH}$ changes resulting from atmospheric sulfur and nitrogen deposition. Geophys. Res. Lett. 41, 935-941. doi: 10.1002/ 2013GL058796

Hamersley, M. R., Turk, K. A., Leinweber, A., Gruber, N., Zehr, J. P., Gunderson, T., et al. (2011). Nitrogen fixation within the water column associated with two hypoxic basins in the Southern California Bight. Aquat. Microb. Ecol. 63, 193-205. doi: 10.3354/ame01494

Hansell, D. A. (2013). Recalcitrant dissolved organic carbon fractions. Annu. Rev. Mar. Sci. 5, 421-445. doi: 10.1146/annurev-marine-120710100757

Hansen, M., and Perner, M. (2016). Hydrogenase gene distribution and $\mathrm{H}_{2}$ consumption ability within the Thiomicrospira lineage. Front. Microbiol. 7:99. doi: $10.3389 /$ fmicb. 2016.00099

Harrison, J. P., Dobinson, L., Freeman, K., McKenzie, R., Wyllie, D., Nixon, S. L., et al. (2015). Aerobically respiring prokaryotic strains exhibit a broader temperature-pH-salinity space for cell division than anaerobically respiring and fermentative strains. J. R. Soc. Interface 12:0658. doi: 10.1098/rsif.2015. 0658

Hattenrath-Lehmann, T. K., Marcoval, M. A., Mittlesdorf, H., Goleski, J. A., Wang, Z., Haynes, B., et al. (2015). Nitrogenous nutrients promote the growth and toxicity of Dinophysis acuminata during estuarine bloom events. PLoS ONE 10:e0124148. doi: 10.1371/journal.pone.0124148

Hatzenpichler, R. (2012). Diversity, physiology, and niche differentiation of ammonia-oxidizing archaea. Appl. Environ. Microbiol. 78, 7501-7510. doi: 10.1128/AEM.01960-12

Hayatsu, M. (1993). The lowest limit of $\mathrm{pH}$ for nitrification in tea soil and isolation of an acidophilic ammonia oxidizing bacterium. Soil Sci. Plant Nutr. 39, 219-226. doi: 10.1080/00380768.1993.10416993

Heiss, E. M., and Fulweiler, R. W. (2016). Coastal water column ammonium and nitrite oxidation are decoupled in summer. Estuar. Coast. Shelf Sci. 178, 110-119. doi: 10.1016/j.ecss.2016.06.002

Henri, P. A., Rommevaux-Jestin, C., Lesongeur, F., Mumford, A., Emerson, D., Godfroy, A., et al. (2016). Structural iron (II) of basaltic glass as an energy source for Zetaproteobacteria in an abyssal plain environment, off the Mid Atlantic Ridge. Front. Microbiol. 6:1518. doi: 10.3389/fmicb.2015.01518

Henstra, A. M., Dijkema, C., and Stams, A. J. (2007). Archaeoglobus fulgidus couples CO oxidation to sulfate reduction and acetogenesis with transient formate accumulation. Environ. Microbiol. 9, 1836-1841. doi: 10.1111/j.14622920.2007.01306.x

Herndl, G. J., Reinthaler, T., Teira, E., van Aken, H., Veth, C., Pernthaler, A., et al. (2005). Contribution of Archaea to total prokaryotic production in the deep Atlantic Ocean. Appl. Environ. Microbiol. 71, 2303-2309. doi: 10.1128/AEM.71. 5.2303-2309.2005

Heymans, J. J., Coll, M., Libralato, S., Morissette, L., and Christensen, V. (2014). Global patterns in ecological indicators of marine food webs: a modelling approach. PLoS ONE 9:e95845. doi: 10.1371/journal.pone. 0095845

Hinrichs, K. U., Hayes, J. M., Sylva, S. P., Brewer, P. G., and DeLong, E. F. (1999). Methane-consuming archaebacteria in marine sediments. Nature 398, 802-805. doi: $10.1038 / 19751$

Hoffmann, L. J., Breitbarth, E., Boyd, P. W., and Hunter, K. A. (2012). Influence of ocean warming and acidification on trace metal biogeochemistry. Mar. Ecol. Prog. Ser. 470, 191-205. doi: 10.3354/meps 10082

Horak, R. E., Qin, W., Schauer, A. J., Armbrust, E. V., Ingalls, A. E., Moffett, J. W., et al. (2013). Ammonia oxidation kinetics and temperature sensitivity of a natural marine community dominated by Archaea. ISME J. 7, 2023-2033. doi: 10.1038 /ismej.2013.75

Hügler, M., and Sievert, S. M. (2011). Beyond the Calvin Cycle: autotrophic carbon fixation in the ocean. Annu. Rev. Mar. Sci. 3, 261-289. doi: 10.1146/annurevmarine-120709-142712

Hunt, D. E., and Ward, C. S. (2015). A network-based approach to disturbance transmission through microbial interactions. Front. Microbiol. 6:1182. doi: $10.3389 /$ fmicb.2015.01182

Hüpeden, J., Wegen, S., Off, S., Lücker, S., Bedarf, Y., Daims, H., et al. (2016). Relative abundance of Nitrotoga spp. in a biofilter of a cold-freshwater aquaculture plant appears to be stimulated by slightly acidic pH. Appl. Environ. Microbiol. 82, 1838-1845. doi: 10.1128/AEM.03163-15
Hutchins, D. A., Mulholland, M. R., and Fu, F. (2009). Nutrient cycles and marine microbes in a CO2-enriched ocean. Oceanography 22, 128-145. doi: 10.5670/ oceanog.2009.103

Ingalls, A. E., Shah, S. R., Hansman, R. L., Aluwihare, L. I., Santos, G. M., Druffel, E. R., et al. (2006). Quantifying archaeal community autotrophy in the mesopelagic ocean using natural radiocarbon. Proc. Natl. Acad. Sci. U.S.A. 103, 6442-6447. doi: 10.1073/pnas.0510157103

Jacquot, J. E., Horak, R. E. A., Amin, S. A., Devol, A. H., Ingalls, A. E., Armbrust, E. V., et al. (2014). Assessment of the potential for copper limitation of ammonia oxidation by Archaea in a dynamic estuary. Mar. Chem. 162, 37-49. doi: 10.1016/j.marchem.2014.02.002

Jaeschke, A., Abbas, B., Zabel, M., Hopmans, E. C., Schouten, S., and Sinninghe Damsté, J. S. (2010). Molecular evidence for anaerobic ammonium-oxidizing (anammox) bacteria in continental shelf and slope sediments off northwest Africa. Limnol. Oceanogr. 55, 365-376. doi: 10.4319/lo.2010.55.1.0365

Jayakumar, A., Al-Rshaidat, M. M., Ward, B. B., and Mulholland, M. R. (2012). Diversity, distribution, and expression of diazotroph nifH genes in oxygendeficient waters of the Arabian Sea. FEMS Microbiol. Ecol. 82, 597-606. doi: 10.1111/j.1574-6941.2012.01430.x

Jelen, B. I., Giovannelli, D., and Falkowski, P. G. (2016). The role of microbial electron transfer in the coevolution of the biosphere and geosphere. Annu. Rev. Microbiol. 70, 45-62. doi: 10.1146/annurev-micro-102215-095521

Jiang, X. X., Dang, H. Y., and Jiao, N. Z. (2015). Ubiquity and diversity of heterotrophic bacterial nas A genes in diverse marine environments. PLoS ONE 10:e0117473. doi: 10.1371/journal.pone.0117473

Jiao, N., Robinson, C., Azam, F., Thomas, H., Baltar, F., Dang, H., et al. (2014). Mechanisms of microbial carbon sequestration in the ocean - future research directions. Biogeosciences 11, 5285-5306. doi: 10.5194/bg-11-5285-2014

Jogler, C. (2014). The bacterial 'mitochondrium'. Mol. Microbiol. 94, 751-755. doi: $10.1111 / \mathrm{mmi} .12814$

Jones, C. M., Stres, B., Rosenquist, M., and Hallin, S. (2008). Phylogenetic analysis of nitrite, nitric oxide, and nitrous oxide respiratory enzymes reveal a complex evolutionary history for denitrification. Mol. Biol. Evol. 25, 1955-1966. doi: 10.1093/molbev/msn146

Jørgensen, B. B., and Boetius, A. (2007). Feast and famine - microbial life in the deep-sea bed. Nat. Rev. Microbiol. 5, 770-781. doi: 10.1038/nrmicro1745

Kallmeyer, J., Pockalny, R., Adhikari, R. R., Smith, D. C., and D'Hondt, S. (2012). Global distribution of microbial abundance and biomass in subseafloor sediment. Proc. Natl. Acad. Sci. U.S.A. 109, 16213-16216. doi: 10.1073/pnas. 1203849109

Karl, D. M., Knauer, G. A., Martin, J. H., and Ward, B. B. (1984). Bacterial chemolithotrophy in the ocean is associated with sinking particles. Nature 309, 54-56. doi: 10.1038/309054a0

Kartal, B., de Almeida, N. M., Maalcke, W. J., Op den Camp, H. J., Jetten, M. S., and Keltjens, J. T. (2013). How to make a living from anaerobic ammonium oxidation. FEMS Microbiol. Rev. 37, 428-461. doi: 10.1111/1574-6976.12014

Kartal, B., Kuypers, M. M., Lavik, G., Schalk, J., Op den Camp, H. J., Jetten, M. S., et al. (2007). Anammox bacteria disguised as denitrifiers: nitrate reduction to dinitrogen gas via nitrite and ammonium. Environ. Microbiol. 9, 635-642. doi: 10.1111/j.1462-2920.2006.01183.x

Kato, S., Ohkuma, M., Powell, D. H., Krepski, S. T., Oshima, K., Hattori, M., et al. (2015). Comparative genomic insights into ecophysiology of neutrophilic, microaerophilic iron oxidizing bacteria. Front. Microbiol. 6:1265. doi: 10.3389/ fmicb.2015.01265

Keeling, R. F., Körtzinger, A., and Gruber, N. (2010). Ocean deoxygenation in a warming world. Annu. Rev. Mar. Sci. 2, 199-229. doi: 10.1146/annurev.marine. 010908.163855

Kellermann, M. Y., Wegener, G., Elvert, M., Yoshinaga, M. Y., Lin, Y. S., Holler, T., et al. (2012). Autotrophy as a predominant mode of carbon fixation in anaerobic methane-oxidizing microbial communities. Proc. Natl. Acad. Sci. U.S.A. 109, 19321-19326. doi: 10.1073/pnas.1208795109

Kim, J. G., Park, S. J., Sinninghe Damsté, J. S., Schouten, S., Rijpstra, W. I., Jung, M. Y., et al. (2016). Hydrogen peroxide detoxification is a key mechanism for growth of ammonia-oxidizing archaea. Proc. Natl. Acad. Sci. U.S.A. 113, 7888-7893. doi: 10.1073/pnas.1605501113

King, G. M., and Weber, C. F. (2007). Distribution, diversity and ecology of aerobic CO-oxidizing bacteria. Nat. Rev. Microbiol. 5, 107-118. doi: 10.1038/ nrmicro1595 
Kirchman, D. L. (2012). Marine archaea take a short cut in the nitrogen cycle. Proc. Natl. Acad. Sci. U.S.A. 109, 17732-17733. doi: 10.1073/pnas.1215 654109

Kirchman, D. L., Elifantz, H., Dittel, A. I., Malmstrom, R. R., and Cottrell, M. T. (2007). Standing stocks and activity of Archaea and Bacteria in the western Arctic Ocean. Limnol. Oceanogr. 52, 495-507. doi: 10.4319/lo.2007.52. 2.0495

Kitidis, V., Laverock, B., McNeill, L. C., Beesley, A., Cummings, D., Tait, K., et al. (2011). Impact of ocean acidification on benthic and water column ammonia oxidation. Geophys. Res. Lett. 38:L21603. doi: 10.1029/2011GL0 49095

Klawonn, I., Bonaglia, S., Brüchert, V., and Ploug, H. (2015a). Aerobic and anaerobic nitrogen transformation processes in $\mathrm{N}_{2}$-fixing cyanobacterial aggregates. ISME J. 9, 1456-1466. doi: 10.1038/ismej. 2014.232

Klawonn, I., Lavik, G., Böning, P., Marchant, H., Dekaezemacker, J., Mohr, W., et al. (2015b). Simple approach for the preparation of ${ }^{15-15} \mathrm{~N}_{2}$-enriched water for nitrogen fixation assessments: evaluation, application and recommendations. Front. Microbiol. 6:769. doi: 10.3389/fmicb.2015.00769

Klotz, M. G. (2010). The grand challenge of microbiology: to know better, protect, utilize and celebrate the unseen majority on our planet. Front. Microbiol. 1:1. doi: $10.3389 /$ fmicb. 2010.00001

Klotz, M. G., Arp, D. J., Chain, P. S., El-Sheikh, A. F., Hauser, L. J., Hommes, N. G., et al. (2006). Complete genome sequence of the marine, chemolithoautotrophic, ammonia-oxidizing bacterium Nitrosococcus oceani ATCC 19707. Appl. Environ. Microbiol. 72, 6299-6315. doi: 10.1128/AEM. 00463-06

Klotz, M. G., and Stein, L. Y. (2008). Nitrifier genomics and evolution of the nitrogen cycle. FEMS Microbiol. Lett. 278, 146-156. doi: 10.1111/j.1574-6968. 2007.00970.x

Knittel, K., and Boetius, A. (2009). Anaerobic oxidation of methane: progress with an unknown process. Annu. Rev. Microbiol. 63, 311-334. doi: 10.1146/annurev. micro.61.080706.093130

Koch, H., Lücker, S., Albertsen, M., Kitzinger, K., Herbold, C., Spieck, E., et al. (2015). Expanded metabolic versatility of ubiquitous nitrite-oxidizing bacteria from the genus Nitrospira. Proc. Natl. Acad. Sci. U.S.A. 112, 11371-11376. doi: 10.1073/pnas.1506533112

Kock, A., Arévalo-Martínez, D. L., Löscher, C. R., and Bange, H. W. (2016). Extreme $\mathrm{N}_{2} \mathrm{O}$ accumulation in the coastal oxygen minimum zone off Peru. Biogeosciences 13, 827-840. doi: 10.5194/bg-13-827-2016

Kolber, Z. (2007). Energy cycle in the ocean: powering the microbial world. Oceanography 20, 79-88. doi: 10.5670/oceanog.2007.51

Könneke, M., Bernhard, A. E., de la Torre, J. R., Walker, C. B., Waterbury, J. B., and Stahl, D. A. (2005). Isolation of an autotrophic ammonia-oxidizing marine archaeon. Nature 437, 543-546. doi: 10.1038/nature03911

Könneke, M., Schubert, D. M., Brown, P. C., Hügler, M., Standfest, S., Schwander, T., et al. (2014). Ammonia-oxidizing archaea use the most energyefficient aerobic pathway for $\mathrm{CO}_{2}$ fixation. Proc. Natl. Acad. Sci. U.S.A. 111, 8239-8244. doi: 10.1073/pnas.1402028111

Koper, T. E., El-Sheikh, A. F., Norton, J. M., and Klotz, M. G. (2004). Ureaseencoding genes in ammonia-oxidizing bacteria. Appl. Environ. Microbiol. 70, 2342-2348. doi: 10.1128/AEM.70.4.2342-2348.2004

Kouzuma, A., Kato, S., and Watanabe, K. (2015). Microbial interspecies interactions: recent findings in syntrophic consortia. Front. Microbiol. 6:477. doi: 10.3389/fmicb.2015.00477

Kozlowski, J. A., Stieglmeier, M., Schleper, C., Klotz, M. G., and Stein, L. Y. (2016). Pathways and key intermediates required for obligate aerobic ammoniadependent chemolithotrophy in bacteria and Thaumarchaeota. ISME J. 10, 1836-1845. doi: 10.1038/ismej.2016.2

Krupke, A., Hmelo, L. R., Ossolinski, J. E., Mincer, T. J., and Van Mooy, B. A. S. (2016). Quorum sensing plays a complex role in regulating the enzyme hydrolysis activity of microbes associated with sinking particles in the ocean. Front. Mar. Sci. 3:55. doi: 10.3389/fmars.2016.00055

Kuypers, M. M. (2015). A division of labour combined. Nature 528, 487-488. doi: $10.1038 / 528487$ a

Kuypers, M. M. M., Sliekers, A. O., Lavik, G., Schmid, M., Jøgensen, B. B., Kuenen, J. G., et al. (2003). Anaerobic ammonium oxidation by anammox bacteria in the Black Sea. Nature 422, 608-611. doi: 10.1038/nature01472
Lam, P., Jensen, M. M., Kock, A., Lettmann, K. A., Plancherel, Y., Lavik, G., et al. (2011). Origin and fate of the secondary nitrite maximum in the Arabian Sea. Biogeosciences 8, 1565-1577. doi: 10.5194/bg-8-1565-2011

Lam, P., and Kuypers, M. M. M. (2011). Microbial nitrogen cycling processes in oxygen minimum zones. Annu. Rev. Mar. Sci. 3, 317-345. doi: 10.1146/ annurev-marine-120709-142814

Lane, N., Martin, W. F., Raven, J. A., and Allen, J. F. (2013). Energy, genes and evolution: introduction to an evolutionary synthesis. Philos. Trans. R. Soc. B 368:20120253. doi: 10.1098/rstb.2012.0253

LaRowe, D. E., and Amend, J. P. (2015). Power limits for microbial life. Front. Microbiol. 6:718. doi: 10.3389/fmicb.2015.00718

Lehtovirta-Morley, L. E., Sayavedra-Soto, L. A., Gallois, N., Schouten, S., Stein, L. Y., Prosser, J. I., et al. (2016). Identifying potential mechanisms enabling acidophily in the ammonia-oxidizing archaeon "Candidatus Nitrosotalea devanaterra”. Appl. Environ. Microbiol. 82, 2608-2619. doi: 10.1128/AEM. 04031- 15

Leong, S. C., Murata, A., Nagashima, Y., and Taguchi, S. (2004). Variability in toxicity of the dinoflagellate Alexandrium tamarense in response to different nitrogen sources and concentrations. Toxicon 43, 407-415. doi: 10.1016/j. toxicon.2004.01.015

Levin, L. A., and Le Bris, N. (2015). The deep ocean under climate change. Science 350, 766-768. doi: 10.1126/science.aad0126

Litchman, E., Edwards, K. F., and Klausmeier, C. A. (2015). Microbial resource utilization traits and trade-offs: implications for community structure, functioning, and biogeochemical impacts at present and in the future. Front. Microbiol. 6:254. doi: 10.3389/fmicb.2015.00254

Liu, B., Frostegård, A., and Bakken, L. R. (2014). Impaired reduction of $\mathrm{N}_{2} \mathrm{O}$ to $\mathrm{N}_{2}$ in acid soils is due to a posttranscriptional interference with the expression of nosZ. mBio 5:e01383-14. doi: 10.1128/mBio.01383-14

Loescher, C. R., Großkopf, T., Desai, F. D., Gill, D., Schunck, H., Croot, P. L., et al. (2014). Facets of diazotrophy in the oxygen minimum zone waters off Peru. ISME J. 8, 2180-2192. doi: 10.1038/ismej.2014.71

Lomas, M. W., and Lipschultz, F. (2006). Forming the primary nitrite maximum: nitrifiers or phytoplankton? Limnol. Oceanogr. 51, 2453-2467. doi: 10.4319/lo. 2006.51.5.2453

Lønborg, C., Cuevas, L. A., Reinthaler, T., Herndl, G. J., Gasol, J. M., Morán, X. A. G., et al. (2016). Depth dependent relationships between temperature and ocean heterotrophic prokaryotic production. Front. Mar. Sci. 3:90. doi: 10.3389/fmars.2016.00090

Löscher, C. R., Bange, H. W., Schmitz, R. A., Callbeck, C. M., Engel, A., Hauss, H., et al. (2016). Water column biogeochemistry of oxygen minimum zones in the eastern tropical North Atlantic and eastern tropical South Pacific oceans. Biogeosciences 13, 3585-3606. doi: 10.5194/bg-13-3585-2016

Lu, L., and Jia, Z. (2013). Urease gene-containing Archaea dominate autotrophic ammonia oxidation in two acid soils. Environ. Microbiol. 15, 1795-1809. doi: 10.1111/1462-2920.12071

Lücker, S., Nowka, B., Rattei, T., Spieck, E., and Daims, H. (2013). The genome of Nitrospina gracilis illuminates the metabolism and evolution of the major marine nitrite oxidizer. Front. Microbiol. 4:27. doi: 10.3389/fmicb.2013.00027

Lücker, S., Wagner, M., Maixner, F., Pelletier, E., Koch, H., Vacherie, B., et al. (2010). A Nitrospira metagenome illuminates the physiology and evolution of globally important nitrite-oxidizing bacteria. Proc. Natl. Acad. Sci. U.S.A. 107, 13479-13484. doi: 10.1073/pnas.1003860107

Lui, H. K., Chen, C. T. A., Lee, J., Bai, Y., and He, X. Q. (2014). Looming hypoxia on outer shelves caused by reduced ventilation in the open oceans: case study of the East China Sea. Estuar. Coast. Shelf Sci. 151, 355-360. doi: 10.1016/j.ecss. 2014.08.010

Lui, H. K., Chen, C. T. A., Lee, J., Wang, S. L., Gong, G. C., Bai, Y., et al. (2015). Acidifying intermediate water accelerates the acidification of seawater on shelves: an example of the East China Sea. Continent. Shelf Res. 111, 223-233. doi: 10.1016/j.csr.2015.08.014

Luo, H., Tolar, B. B., Swan, B. K., Zhang, C. L., Stepanauskas, R., Moran, M. A., et al. (2014). Single-cell genomics shedding light on marine Thaumarchaeota diversification. ISME J. 8, 732-736. doi: 10.1038/ismej.2013.202

Mahaffey, C., Michaels, A. F., and Capone, D. G. (2005). The conundrum of marine $\mathrm{N}_{2}$ fixation. Am. J. Sci. 305, 546-595. doi: 10.2475/ajs.305.6-8.546

Marin, B., Nowack, E. C., Glöckner, G., and Melkonian, M. (2007). The ancestor of the Paulinella chromatophore obtained a carboxysomal operon by horizontal 
gene transfer from a Nitrococcus-like $\gamma$-proteobacterium. BMC Evol. Biol. 7:85. doi: 10.1186/1471-2148-7-85

Marlow, J. J., Skennerton, C. T., Li, Z., Chourey, K., Hettich, R. L., Pan, C., et al. (2016). Proteomic stable isotope probing reveals biosynthesis dynamics of slow growing methane based microbial communities. Front. Microbiol. 7:563. doi: $10.3389 /$ fmicb. 2016.00563

Martens-Habbena, W., Berube, P. M., Urakawa, H., de la Torre, J. R., and Stahl, D. A. (2009). Ammonia oxidation kinetics determine niche separation of nitrifying Archaea and Bacteria. Nature 461, 976-979. doi: 10.1038/nature 08465

Martin, W., Baross, J., Kelley, D., and Russell, M. J. (2008). Hydrothermal vents and the origin of life. Nat. Rev. Microbiol. 6, 805-814. doi: 10.1038/nrmicro1991

Martin, W. F., Sousa, F. L., and Lane, N. (2014). Energy at life's origin. Science 344, 1092-1093. doi: 10.1126/science. 1251653

Martínez-Cano, D. J., Reyes-Prieto, M., Martínez-Romero, E., Partida-Martínez, L. P., Latorre, A., Moya, A., et al. (2015). Evolution of small prokaryotic genomes. Front. Microbiol. 5:742. doi: 10.3389/fmicb.2014.00742

Masuda, S., Awaji, T., Sugiura, N., Matthews, J. P., Toyoda, T., Kawai, Y., et al. (2010). Simulated rapid warming of abyssal North Pacific waters. Science 329, 319-322. doi: 10.1126/science.1188703

McBeth, J. M., and Emerson, D. (2016). In situ microbial community succession on mild steel in estuarine and marine environments: exploring the role of iron-oxidizing bacteria. Front. Microbiol. 7:767. doi: 10.3389/fmicb.2016. 00767

McBeth, J. M., Little, B. J., Ray, R. I., Farrar, K. M., and Emerson, D. (2011). Neutrophilic iron-oxidizing "Zetaproteobacteria" and mild steel corrosion in nearshore marine environments. Appl. Environ. Microbiol. 77, 1405-1412. doi: 10.1128/AEM.02095-10

Mellbye, B. L., Giguere, A., Chaplen, F., Bottomley, P. J., and Sayavedra-Soto, L. A. (2016). Steady-state growth under inorganic carbon limitation conditions increases energy consumption for maintenance and enhances nitrous oxide production in Nitrosomonas europaea. Appl. Environ. Microbiol. 82, 3310-3318. doi: 10.1128/AEM.00294-16

Merbt, S. N., Stahl, D. A., Casamayor, E. O., Martí, E., Nicol, G. W., and Prosser, J. I. (2012). Differential photoinhibition of bacterial and archaeal ammonia oxidation. FEMS Microbiol. Lett. 327, 41-46. doi: 10.1111/j.1574-6968.2011. 02457.x

Metcalf, W. W., Griffin, B. M., Cicchillo, R. M., Gao, J., Janga, S. C., Cooke, H. A., et al. (2012). Synthesis of methylphosphonic acid by marine microbes: a source for methane in the aerobic ocean. Science 337, 1104-1107. doi: 10.1126/science. 1219875

Middelburg, J. J., and Levin, L. A. (2009). Coastal hypoxia and sediment biogeochemistry. Biogeosciences 6, 1273-1293. doi: 10.5194/bg-6-1273-2009

Millero, F. J., Ryan, W., Benjamin, D., and Jason, W. (2009). Effect of ocean acidification on the speciation of metals in seawater. Oceanography 22, 74-85. doi: 10.5670/oceanog.2009.98

Miyazaki, J., Higa, R., Toki, T., Ashi, J., Tsunogai, U., Nunoura, T., et al. (2009). Molecular characterization of potential nitrogen fixation by anaerobic methaneoxidizing archaea in the methane seep sediments at the number 8 Kumano Knoll in the Kumano Basin, offshore of Japan. Appl. Environ. Microbiol. 75, 7153-7162. doi: 10.1128/AEM.01184-09

Moore, C. M., Mills, M. M., Arrigo, K. R., Berman-Frank, I., Bopp, L., Boyd, P. W., et al. (2013). Processes and patterns of oceanic nutrient limitation. Nat. Geosci. 6, 701-710. doi: 10.1038/NGEO1765

Mora, C., Wei, C. L., Rollo, A., Amaro, T., Baco, A. R., Billett, D., et al. (2013). Biotic and human vulnerability to projected changes in ocean biogeochemistry over the 21st century. PLoS Biol. 11:e1001682. doi: 10.1371/journal.pbio. 1001682

Moran, M. A., Kujawinski, E. B., Stubbins, A., Fatland, R., Aluwihare, L. I., Buchan, A., et al. (2016). Deciphering ocean carbon in a changing world. Proc. Natl. Acad. Sci. U.S.A 113, 3143-3151. doi: 10.1073/pnas.15146 45113

Morel, F. M., and Price, N. M. (2003). The biogeochemical cycles of trace metals in the oceans. Science 300, 944-947. doi: 10.1126/science.1083545

Morris, R. M., Nunn, B. L., Frazar, C., Goodlett, D. R., Ting, Y. S., and Rocap, G. (2010). Comparative metaproteomics reveals ocean-scale shifts in microbial nutrient utilization and energy transduction. ISME J. 4, 673-685. doi: 10.1038/ ismej. 2010.4
Murray, R. H., Erler, D. V., and Eyre, B. D. (2015). Nitrous oxide fluxes in estuarine environments: response to global change. Glob. Chang. Biol. 21, 3219-3245. doi: $10.1111 /$ gcb. 12923

Naqvi, S. W. A., Bange, H. W., Farías, L., Monteiro, P. M. S., Scranton, M. I., and Zhang, J. (2010). Marine hypoxia/anoxia as a source of $\mathrm{CH}_{4}$ and $\mathrm{N}_{2} \mathrm{O}$. Biogeosciences 7, 2159-2190. doi: 10.5194/bg-7-2159-2010

Ngugi, D. K., Blom, J., Stepanauskas, R., and Stingl, U. (2016). Diversification and niche adaptations of Nitrospina-like bacteria in the polyextreme interfaces of Red Sea brines. ISME J. 10, 1383-1399. doi: 10.1038/ismej.2015.214

Nisbet, E. G., and Sleep, N. H. (2001). The habitat and nature of early life. Nature 409, 1083-1091. doi: 10.1038/35059210

Nitschke, W., McGlynn, S. E., Milner-White, E. J., and Russell, M. J. (2013). On the antiquity of metalloenzymes and their substrates in bioenergetics. Biochim. Biophys. Acta 1827, 871-881. doi: 10.1016/j.bbabio.2013.02.008

Nogales, B., Lanfranconi, M. P., Piña-Villalonga, J. M., and Bosch, R. (2011). Anthropogenic perturbations in marine microbial communities. FEMS Microbiol. Rev. 35, 275-298. doi: 10.1111/j.1574-6976.2010.00248.x

Nowka, B., Daims, H., and Spieck, E. (2015). Comparison of oxidation kinetics of nitrite-oxidizing bacteria: nitrite availability as a key factor in niche differentiation. Appl. Environ. Microbiol. 81, 745-753. doi: 10.1128/AEM. 02734-14

O’Brien, P. A., Morrow, K. M., Willis, B. L., and Bourne, D. G. (2016). Implications of ocean acidification for marine microorganisms from the free-living to the host-associated. Front. Mar. Sci. 3:47. doi: 10.3389/fmars.2016.00047

Odum, E. P. (1968). Energy flow in ecosystems: a historical review. Am. Zool. 8, 11-18. doi: 10.1093/icb/8.1.11

Offre, P., Kerou, M., Spang, A., and Schleper, C. (2014). Variability of the transporter gene complement in ammonia-oxidizing archaea. Trends Microbiol. 22, 665-675. doi: 10.1016/j.tim.2014.07.007

Orcutt, B. N., Sylvan, J. B., Knab, N. J., and Edwards, K. J. (2011). Microbial ecology of the dark ocean above, at, and below the seafloor. Microbiol. Mol. Biol. Rev. 75, 361-422. doi: 10.1128/MMBR.00039-10

Orcutt, B. N., Sylvan, J. B., Rogers, D. R., Delaney, J., Lee, R. W., and Girguis, P. R. (2015). Carbon fixation by basalt-hosted microbial communities. Front. Microbiol. 6:904. doi: 10.3389/fmicb.2015.00904

Oshiki, M., Satoh, H., and Okabe, S. (2016). Ecology and physiology of anaerobic ammonium oxidizing bacteria. Environ. Microbiol. 18, 2784-2796. doi: 10.1111/ 1462-2920.13134

Palatinszky, M., Herbold, C., Jehmlich, N., Pogoda, M., Han, P., von Bergen, M., et al. (2015). Cyanate as an energy source for nitrifiers. Nature 524, 105-108. doi: $10.1038 /$ nature 14856

Paul, K., Nonoh, J. O., Mikulski, L., and Brune, A. (2012). “Methanoplasmatales," Thermoplasmatales-related archaea in termite guts and other environments, are the seventh order of methanogens. Appl. Environ. Microbiol. 78, 8245-8253. doi: 10.1128/AEM.02193-12

Paull, C. K., Jull, A. J. T., Toolin, L. J., and Linick, T. (1985). Stable isotope evidence for chemosynthesis in an abyssal seep community. Nature 317, 709-711. doi: 10.1038/317709a0

Peck, H. D. Jr. (1968). Energy-coupling mechanisms in chemolithotrophic bacteria. Annu. Rev. Microbiol. 22, 489-518. doi: 10.1146/annurev.mi.22.100168.002421

Perez-Garcia, O., Lear, G., and Singhal, N. (2016). Metabolic network modeling of microbial interactions in natural and engineered environmental systems. Front. Microbiol. 7:673. doi: 10.3389/fmicb.2016.00673

Pernthaler, A., Dekas, A. E., Brown, C. T., Goffredi, S. K., Embaye, T., and Orphan, V. J. (2008). Diverse syntrophic partnerships from deepsea methane vents revealed by direct cell capture and metagenomics. Proc. Natl. Acad. Sci. U.S.A. 105, 7052-7057. doi: 10.1073/pnas.07113 03105

Pfeiffer, T., and Schuster, S. (2005). Game-theoretical approaches to studying the evolution of biochemical systems. Trends Biochem. Sci. 30, 20-25. doi: 10.1016/ j.tibs.2004.11.006

Phillips, C. J., Smith, Z., Embley, T. M., and Prosser, J. I. (1999). Phylogenetic differences between particle-associated and planktonic ammonia-oxidizing bacteria of the $\beta$ subdivision of the class Proteobacteria in the northwestern Mediterranean Sea. Appl. Environ. Microbiol. 65, 779-786.

Ploug, H., and Bergkvist, J. (2015). Oxygen diffusion limitation and ammonium production within sinking diatom aggregates under hypoxic and anoxic conditions. Mar. Chem. 176, 142-149. doi: 10.1016/j.marchem.2015.08.012 
Pommerening-Röser, A., and Koops, H. P. (2005). Environmental pH as an important factor for the distribution of urease positive ammonia-oxidizing bacteria. Microbiol. Res. 160, 27-35. doi: 10.1016/j.micres.2004.09.006

Qin, W., Amin, S. A., Martens-Habbena, W., Walker, C. B., Urakawa, H., Devol, A. H., et al. (2014). Marine ammonia-oxidizing archaeal isolates display obligate mixotrophy and wide ecotypic variation. Proc. Natl. Acad. Sci. U.S.A. 111, 12504-12509. doi: 10.1073/pnas.1324115111

Rattray, J. E. (2008). Ladderane Lipids in Anammox Bacteria: Occurrence, Biosynthesis and Application as Environmental Markers. Ph.D. thesis, University of Utrecht, Utrecht.

Reed, D. C., Breier, J. A., Jiang, H., Anantharaman, K., Klausmeier, C. A., Toner, B. M., et al. (2015). Predicting the response of the deep-ocean microbiome to geochemical perturbations by hydrothermal vents. ISME J. 9, 1857-1869. doi: 10.1038/ismej.2015.4

Reinthaler, T., van Aken, H. M., and Herndl, G. J. (2010). Major contribution of autotrophy to microbial carbon cycling in the deep North Atlantic's interior. Deep Sea Res. II 57, 1572-1580. doi: 10.1016/j.dsr2.2010.02.023

Richardson, D., Felgate, H., Watmough, N., Thomson, A., and Baggs, E. (2009). Mitigating release of the potent greenhouse gas $\mathrm{N} 2 \mathrm{O}$ from the nitrogen cycle - could enzymic regulation hold the key? Trends Biotechnol. 27, 388-397. doi: 10.1016/j.tibtech.2009.03.009

Rockström, J., Steffen, W., Noone, K., Persson, A., Chapin, F. S. III., Lambin, E. F., et al. (2009). A safe operating space for humanity. Nature 461, 472-475. doi: $10.1038 / 461472 a$

Russ, L., Kartal, B., Op den Camp, H. J., Sollai, M., Le Bruchec, J., et al. (2013). Presence and diversity of anammox bacteria in cold hydrocarbon-rich seeps and hydrothermal vent sediments of the Guaymas Basin. Front. Microbiol. 4:219. doi: $10.3389 /$ fmicb. 2013.00219

Rysgaard, S., Glud, R. N., Risgaard-Petersen, N., and Dalsgaard, T. (2004). Denitrification and anammox activity in Arctic marine sediments. Limnol. Oceanogr. 49, 1493-1502. doi: 10.4319/lo.2004.49.5.1493

Santoro, A. E., Dupont, C. L., Richter, R. A., Craig, M. T., Carini, P., McIlvin, M. R., et al. (2015). Genomic and proteomic characterization of "Candidatus Nitrosopelagicus brevis": an ammonia-oxidizing archaeon from the open ocean. Proc. Natl. Acad. Sci. U.S.A. 112, 1173-1178. doi: 10.1073/pnas.14162 23112

Santoro, A. E., Sakamoto, C. M., Smith, J. M., Plant, J. N., Gehman, A. L., Worden, A. Z., et al. (2013). Measurements of nitrite production in and around the primary nitrite maximum in the central California Current. Biogeosciences 10, 7395-7410. doi: 10.5194/bg-10-7395-2013

Sauder, L. A., Albertsen, M., Engel, K., Schwarz, J., Nielsen, P. H., Wagner, M., et al. (2017). Cultivation and characterization of Candidatus Nitrosocosmicus exaquare, an ammonia-oxidizing archaeon from a municipal wastewater treatment system. ISME J. 11, 1142-1157. doi: 10.1038/ismej.2016.192

Schaefer, S. C., and Hollibaugh, J. T. (2017). Temperature decouples ammonium and nitrite oxidation in coastal waters. Environ. Sci. Technol. 51, 3157-3164. doi: 10.1021/acs.est.6b03483

Schofield, O., Ducklow, H. W., Martinson, D. G., Meredith, M. P., Moline, M. A., and Fraser, W. R. (2010). How do polar marine ecosystems respond to rapid climate change? Science 328, 1520-1523. doi: 10.1126/science.1185779

Scholz, F., McManus, J., Mix, A. C., Hensen, C., and Schneider, R. R. (2014). The impact of ocean deoxygenation on iron release from continental margin sediments. Nat. Geosci. 7, 433-477. doi: 10.1038/NGEO2162

Schreiber, F., Wunderlin, P., Udert, K. M., and Wells, G. F. (2012). Nitric oxide and nitrous oxide turnover in natural and engineered microbial communities: biological pathways, chemical reactions, and novel technologies. Front. Microbiol. 3:372. doi: 10.3389/fmicb.2012.00372

Schumann, W. (2009). Temperature sensors of eubacteria. Adv. Appl. Microbiol. 67, 213-256. doi: 10.1016/S0065-2164(08)01007-1

Shanks, A. L., and Trent, J. D. (1979). Marine snow: microscale nutrient patches. Limnol. Oceanogr. 24, 850-854. doi: 10.4319/lo.1979.24.5.0850

Shao, M. F., Zhang, T., and Fang, H. H. (2010). Sulfur-driven autotrophic denitrification: diversity, biochemistry, and engineering applications. Appl. Microbiol. Biotechnol. 88, 1027-1042. doi: 10.1007/s00253-010-2847-1

Shao, S. D., Luan, X. W., Dang, H. Y., Zhou, H. X., Zhao, Y. K., Liu, H. T., et al. (2014). Deep-sea methane seep sediments in the Okhotsk Sea sustain diverse and abundant anammox bacteria. FEMS Microbiol. Ecol. 87, 503-516. doi: $10.1111 / 1574-6941.12241$
Shiozaki, T., Ijichi, M., Isobe, K., Hashihama, F., Nakamura, K. I., Ehama, M., et al. (2016). Nitrification and its influence on biogeochemical cycles from the equatorial Pacific to the Arctic Ocean. ISME J. 10, 2184-2197. doi: 10.1038/ ismej.2016.18

Sievert, S. M., Scott, K. M., Klotz, M. G., Chain, P. S., Hauser, L. J., Hemp, J., et al. (2008). Genome of the epsilonproteobacterial chemolithoautotroph Sulfurimonas denitrificans. Appl. Environ. Microbiol. 74, 1145-1156. doi: 10.1128/AEM.01844-07

Simon, J., and Klotz, M. G. (2013). Diversity and evolution of bioenergetic systems involved in microbial nitrogen compound transformations. Biochim. Biophys. Acta 1827, 114-135. doi: 10.1016/j.bbabio.2012.07.005

Smith, J. M., Chavez, F. P., and Francis, C. A. (2014). Ammonium uptake by phytoplankton regulates nitrification in the sunlit ocean. PLoS ONE 9:e108173. doi: 10.1371 /journal.pone.0108173

Soh, K. C., and Hatzimanikatis, V. (2010). Network thermodynamics in the postgenomic era. Curr. Opin. Microbiol. 13, 350-357. doi: 10.1016/j.mib.2010. 03.001

Solomon, C. M., Collier, J. L., Berg, G. M., and Glibert, P. M. (2010). Role of urea in microbial metabolism in aquatic systems: a biochemical and molecular review. Aquat. Microb. Ecol. 59, 67-88. doi: 10.3354/ame01390

Sonthiphand, P., Hall, M. W., and Neufeld, J. D. (2014). Biogeography of anaerobic ammonia-oxidizing (anammox) bacteria. Front. Microbiol. 5:399. doi: 10.3389/ fmicb.2014.00399

Sousa, F. L., Thiergart, T., Landan, G., Nelson-Sathi, S., Pereira, I. A., Allen, J. F., et al. (2013). Early bioenergetic evolution. Philos. Trans. R. Soc. B 368:20130088. doi: 10.1098/rstb.2013.0088

Spang, A., Hatzenpichler, R., Brochier-Armanet, C., Rattei, T., Tischler, P., Spieck, E., et al. (2010). Distinct gene set in two different lineages of ammoniaoxidizing archaea supports the phylum Thaumarchaeota. Trends Microbiol. 18, 331-340. doi: 10.1016/j.tim.2010.06.003

Spang, A., Poehlein, A., Offre, P., Zumbrägel, S., Haider, S., Rychlik, N., et al. (2012). The genome of the ammonia-oxidizing Candidatus Nitrososphaera gargensis: insights into metabolic versatility and environmental adaptations. Environ. Microbiol. 14, 3122-3145. doi: 10.1111/j.1462-2920.2012. 02893.x

Spieck, E., Keuter, S., Wenzel, T., Bock, E., and Ludwig, W. (2014). Characterization of a new marine nitrite oxidizing bacterium, Nitrospina watsonii sp. nov., a member of the newly proposed phylum "Nitrospinae". Syst. Appl. Microbiol. 37, 170-176. doi: 10.1016/j.syapm.2013.12.005

Spielhagen, R. F., Werner, K., Sørensen, S. A., Zamelczyk, K., Kandiano, E., Budeus, G., et al. (2011). Enhanced modern heat transfer to the Arctic by warm Atlantic Water. Science 331, 450-453. doi: 10.1126/science.1197397

Stahl, D. A., and de la Torre, J. R. (2012). Physiology and diversity of ammoniaoxidizing archaea. Annu. Rev. Microbiol. 66, 83-101. doi: 10.1146/annurevmicro-092611-150128

Starkenburg, S. R., Chain, P. S., Sayavedra-Soto, L. A., Hauser, L., Land, M. L., Larimer, F. W., et al. (2006). Genome sequence of the chemolithoautotrophic nitrite-oxidizing bacterium Nitrobacter winogradskyi Nb-255. Appl. Environ. Microbiol. 72, 2050-2063. doi: 10.1128/AEM.72.3.2050-2063.2006

Statham, P. J. (2012). Nutrients in estuaries - an overview and the potential impacts of climate change. Sci. Total Environ. 434, 213-227. doi: 10.1016/j.scitotenv. 2011.09 .088

Stein, L. Y., and Klotz, M. G. (2016). The nitrogen cycle. Curr. Biol. 26, R94-R98. doi: 10.1016/j.cub.2015.12.021

Stief, P., Kamp, A., Thamdrup, B., and Glud, R. N. (2016). Anaerobic nitrogen turnover by sinking diatom aggregates at varying ambient oxygen levels. Front. Microbiol. 7:98. doi: 10.3389/fmicb.2016.00098

Stockdale, A., Tipping, E., Lofts, S., and Mortimer, R. J. (2016). Effect of ocean acidification on organic and inorganic speciation of trace metals. Environ. Sci. Technol. 50, 1906-1913. doi: 10.1021/acs.est.5b05624

Strom, S. L. (2008). Microbial ecology of ocean biogeochemistry: a community perspective. Science 320, 1043-1045. doi: 10.1126/science.1153527

Strous, M., Fuerst, J. A., Kramer, E. H., Logemann, S., Muyzer, G., van de Pas-Schoonen, K. T., et al. (1999). Missing lithotroph identified as new planctomycete. Nature 400, 446-449. doi: 10.1038/22749

Sunda, W. G. (2012). Feedback interactions between trace metal nutrients and phytoplankton in the ocean. Front. Microbiol. 3:204. doi: 10.3389/fmicb.2012. 00204 
Sydeman, W. J., García-Reyes, M., Schoeman, D. S., Rykaczewski, R. R., Thompson, S. A., Black, B. A., et al. (2014). Climate change and wind intensification in coastal upwelling ecosystems. Science 345, 77-80. doi: 10.1126/science. 1251635

Tait, K., Laverock, B., and Widdicombe, S. (2014). Response of an Arctic sediment nitrogen cycling community to increased $\mathrm{CO}_{2}$. Estuar. Coasts 37, 724-735. doi: 10.1007/s12237-013-9709-x

Taylor, A. E., Giguere, A. T., Zoebelein, C. M., Myrold, D. D., and Bottomley, P. J. (2017). Modeling of soil nitrification responses to temperature reveals thermodynamic differences between ammonia-oxidizing activity of archaea and bacteria. ISME J. 11, 896-908. doi: 10.1038/ismej.2016.179

Taylor, G. T., Iabichella, M., Ho, T. Y., Scranton, M. I., Thunell, R. C., MullerKarger, F., et al. (2001). Chemoautotrophy in the redox transition zone of the Cariaco Basin: a significant midwater source of organic carbon production. Limnol. Oceanogr. 46, 148-163. doi: 10.4319/lo.2001.46.1.0148

Thamdrup, B., and Dalsgaard, T. (2002). Production of $\mathrm{N}_{2}$ through anaerobic ammonium oxidation coupled to nitrate reduction in marine sediments. Appl. Environ. Microbiol. 68, 1312-1318. doi: 10.1128/AEM.68.3.1312-1318.2002

Tolar, B. B., Wallsgrove, N. J., Popp, B. N., and Hollibaugh, J. T. (2016). Oxidation of urea-derived nitrogen by thaumarchaeota-dominated marine nitrifying communities. Environ. Microbiol. doi: 10.1111/1462-2920.13457 [Epub ahead of print].

Tolner, B., Poolman, B., and Konings, W. N. (1997). Adaptation of microorganisms and their transport systems to high temperatures. Comp. Biochem. Physiol. 118, 423-428. doi: 10.1016/S0300-9629(97)00003-0

Tourna, M., Freitag, T. E., Nicol, G. W., and Prosser, J. I. (2008). Growth, activity and temperature responses of ammonia-oxidizing archaea and bacteria in soil microcosms. Environ. Microbiol. 10, 1357-1364. doi: 10.1111/j.1462-2920.2007. 01563.x

Townsend-Small, A., Prokopenko, M. G., and Berelson, W. M. (2014). Nitrous oxide cycling in the water column and sediments of the oxygen minimum zone, eastern subtropical North Pacific, Southern California, and Northern Mexico $\left(23^{\circ} \mathrm{N}-34^{\circ} \mathrm{N}\right)$. J. Geophys. Res. Oceans 119, 3158-3170. doi: 10.1002/ 2013JC009580

Tseng, H. C., Chen, C. T. A., Borges, A. V., DelValls, T. A., Lai, C. M., and Chen, T. Y. (2016). Distributions and sea-to-air fluxes of nitrous oxide in the South China Sea and the West Philippines Sea. Deep Sea Res. I 115, 131-144. doi: 10.1016/j.dsr.2016.06.006

Turner, J. T. (2015). Zooplankton fecal pellets, marine snow, phytodetritus and the ocean's biological pump. Progr. Oceanogr. 130, 205-248. doi: 10.1016/j.pocean. 2014.08.005

Ulloa, O., Canfield, D. E., DeLong, E. F., Letelier, R. M., and Stewart, F. J. (2012). Microbial oceanography of anoxic oxygen minimum zones. Proc. Natl. Acad. Sci. U.S.A. 109, 15996-16003. doi: 10.1073/pnas.1205009109

Vallino, J. J., and Algar, C. K. (2016). The thermodynamics of marine biogeochemical cycles: lotka revisited. Ann. Rev. Mar. Sci. 8, 333-356. doi: 10.1146/annurev-marine-010814-015843

van Kessel, M. A., Speth, D. R., Albertsen, M., Nielsen, P. H., Op den Camp, H. J., Kartal, B., et al. (2015). Complete nitrification by a single microorganism. Nature 528, 555-559. doi: 10.1038/nature16459

van Leeuwen, S. M., Le Quesne, W. F., and Parker, E. R. (2016). Potential future fisheries yields in shelf waters: a model study of the effects of climate change and ocean acidification. Biogeosciences 13, 441-454. doi: 10.5194/bg-13-441-2016

Van Mooy, B. A., Krupke, A., Dyhrman, S. T., Fredricks, H. F., Frischkorn, K. R., Ossolinski, J. E., et al. (2015). Major role of planktonic phosphate reduction in the marine phosphorus redox cycle. Science 348, 783-785. doi: 10.1126/science. aaa8181

van Niftrik, L., and Jetten, M. S. (2012). Anaerobic ammonium-oxidizing bacteria: unique microorganisms with exceptional properties. Microbiol. Mol. Biol. Rev. 76, 585-596. doi: 10.1128/MMBR.05025-11

Voss, M., Bange, H. W., Dippner, J. W., Middelburg, J. J., Montoya, J. P., and Ward, B. (2013). The marine nitrogen cycle: recent discoveries, uncertainties and the potential relevance of climate change. Philos. Trans. R. Soc. B 368, 20130121. doi: 10.1098/rstb.2013.0121
Walker, C. B., de la Torre, J. R., Klotz, M. G., Urakawa, H., Pinel, N., Arp, D. J., et al. (2010). Nitrosopumilus maritimus genome reveals unique mechanisms for nitrification and autotrophy in globally distributed marine crenarchaea. Proc. Natl. Acad. Sci. U.S.A 107, 8818-8823. doi: 10.1073/pnas.0913533107

Wang, D., Gouhier, T. C., Menge, B. A., and Ganguly, A. R. (2015). Intensification and spatial homogenization of coastal upwelling under climate change. Nature 518, 390-394. doi: 10.1038/nature14235

Wang, L., Cheung, M. K., Kwan, H. S., Hwang, J.-S., and Wong, C. K. (2015). Microbial diversity in shallow-water hydrothermal sediments of Kueishan Island, Taiwan as revealed by pyrosequencing. J. Basic Microbiol. 55, 1308-1318. doi: 10.1002/jobm.201400811

Wang, L., Lim, C. K., Dang, H. Y., Hanson, T. E., and Klotz, M. G. (2016). D1FHS, the type strain of the ammonia-oxidizing bacterium Nitrosococcus wardiae spec. nov.: enrichment, isolation, phylogenetic, and growth physiological characterization. Front. Microbiol. 7:512. doi: 10.3389/fmicb.2016.00512

Ward, B. B., Devol, A. H., Rich, J. J., Chang, B. X., Bulow, S. E., Naik, H., et al. (2009). Denitrification as the dominant nitrogen loss process in the Arabian Sea. Nature 461, 78-81. doi: 10.1038/nature08276

Widdicombe, S., and Needham, H. R. (2007). Impact of CO2-induced seawater acidification on the burrowing activity of Nereis virens and sediment nutrient flux. Mar. Ecol. Prog. Ser. 341, 111-122. doi: 10.3354/meps341111

Widdicombe, S., and Spicer, J. I. (2008). Predicting the impact of ocean acidification on benthic biodiversity: what can animal physiology tell us? J. Exp. Mar. Biol. Ecol. 366, 187-197. doi: 10.1016/j.jembe.2008.07.024

Woebken, D., Fuchs, B. M., Kuypers, M. M., and Amann, R. (2007). Potential interactions of particle-associated anammox bacteria with bacterial and archaeal partners in the Namibian upwelling system. Appl. Environ. Microbiol. 73, 4648-4657. doi: 10.1128/AEM.02774-06

Wright, J. J., Konwar, K. M., and Hallam, S. J. (2012). Microbial ecology of expanding oxygen minimum zones. Nat. Rev. Microbiol. 10, 381-394. doi: $10.1038 /$ nrmicro2778

Yakimov, M. M., La Cono, V., Smedile, F., Deluca, T. H., Juárez, S., Ciordia, S., et al. (2011). Contribution of crenarchaeal autotrophic ammonia oxidizers to the dark primary production in Tyrrhenian deep waters (Central Mediterranean Sea). ISME J. 5, 945-961. doi: 10.1038/ismej.2010.197

Zeebe, R. E., and Wolf-Gladrow, D. (2001). $\mathrm{CO}_{2}$ in seawater: equilibrium, kinetics, isotopes. Elsevier Oceanogr. Ser. 65, 362.

Zehr, J. P., and Kudela, R. M. (2011). Nitrogen cycle of the open ocean: from genes to ecosystems. Annu. Rev. Mar. Sci. 3, 197-225. doi: 10.1146/annurev-marine120709-142819

Zeng, X., Chen, X., and Zhuang, J. (2015). The positive relationship between ocean acidification and pollution. Mar. Pollut. Bull. 91, 14-21. doi: 10.1016/j. marpolbul.2014.12.001

Zhou, H., Dang, H., and Klotz, M. G. (2016). Environmental conditions outweigh geographical contiguity in determining the similarity of nifH-harboring microbial communities in sediments of two disconnected marginal seas. Front. Microbiol. 7:1111. doi: 10.3389/fmicb.2016.01111

Zhu, X., Burger, M., Doane, T. A., and Horwath, W. R. (2013). Ammonia oxidation pathways and nitrifier denitrification are significant sources of $\mathrm{N}_{2} \mathrm{O}$ and $\mathrm{NO}$ under low oxygen availability. Proc. Natl. Acad. Sci. U.S.A. 110, 6328-6333. doi: $10.1073 /$ pnas. 1219993110

Conflict of Interest Statement: The authors declare that the research was conducted in the absence of any commercial or financial relationships that could be construed as a potential conflict of interest.

Copyright (c) 2017 Dang and Chen. This is an open-access article distributed under the terms of the Creative Commons Attribution License (CC BY). The use, distribution or reproduction in other forums is permitted, provided the original author(s) or licensor are credited and that the original publication in this journal is cited, in accordance with accepted academic practice. No use, distribution or reproduction is permitted which does not comply with these terms. 